\title{
The role of fluids in the late-stage evolution of the South Mountain Batholith, Nova Scotia: further geochemical and oxygen isotopic studies
}

\author{
Daniel J. Kontak \\ Nova Scotia Department of Mines and Energy, P.O. Box 1087, Halifax, Nova Scotia B3J 2X1, Canada
}

\author{
Robert Kerrich \\ Department of Geological Sciences, University of Saskatchewan, Saskatoon, Saskatchewan \\ S7N OW0, Canada
}

and

\author{
David F. Strong* \\ Department of Earth Sciences, Memorial University of Newfoundland, St. John's, Newfoundland \\ A1B 3X5, Canada
}

Date Received July 26, 1990

Date Accepted January 28, 1991

\begin{abstract}
In order to evaluate the late-stage physical and chemical evolution of the Upper Devonian, peraluminous South Mountain Batholith, mineral chemistry (muscovite, feldspars), oxygen isotopes (whole rock, mineral separates) and Al/Si ordering of $\mathrm{K}$ feldspar have been investigated. Muscovite, $K$-feldspar and albite define coherent chemical trends with respect to compatible $(\mathrm{Ba}, \mathrm{Sr}, \mathrm{Eu})$ and incompatible ( $\mathrm{Li}, \mathrm{Cs}, \mathrm{Rb})$ elements such that crystal fractionation processes are reflected. However, the influence of a fluid phase is seen in terms of Eu/Eu* of greisen muscovite and the light REE profiles (chondritic) of chemically evolved $\mathrm{K}$-feldspar. The dominance of monoclinic $\mathrm{K}$-feldspar, even in pegmatitic environments, indicates that either single or multiple processes impeded $\mathrm{Al} / \mathrm{Si}$ ordering (e.g., cooling rate, fluid and/or rock composition). However, locally the development of triclinic K-feldspar dominates where intense fluid-rock interaction occurred (e.g., greisens), thus reflecting alteration at temperatures $\leq 450^{\circ} \mathrm{C}$. $\delta^{18} \mathrm{O}$ values of minerals from pegmatites reflect disequilibrium conditions related to variable degrees of fluid-rock interaction after crystallization. Calculated $\delta^{18} \mathrm{O}_{\text {nujd }}$ (mostly 5-10\%) indicates a dominantly magmatic fluid reservoir; both ${ }^{18}$-enriched $($ to $+18 \%$ ) and -depleted $($ to $<+4 \%$ ) fluids infiltrated the system, indicating that local fluid mixing occurred.
\end{abstract}

Dans le but d'évaluer l'évolution physique et chimique dans ses derniers stades du batholite péralumineux dévonien supérieur de South Mountain, on a étudié la chimie des minéraux (muscovite, feldspaths), les isotopes de l'oxygène (sur roche totale et sur fractions monominérales) et l'ordonnance $\mathrm{Al} / \mathrm{Si}$ au sein des feldspaths potassiques. La muscovite, le feldspath potassique et l'albite déterminent des tendances chimiques cohérentes vis-à-vis des éléments compatibles $(\mathrm{Ba}, \mathrm{Sr}, \mathrm{Eu})$ et incompatibles $(\mathrm{Li}$, $\mathrm{Cs}, \mathrm{Rb}$ ), de façon telle qu'elles reflètent des processus de cristallisation fractionnée. Cependant, l'influence d'une phase fluide s'exprime en termes du rapport Eu/Eu* des muscovites dans les greisens et des profils (chondritiques) des T.R. légères de feldspaths potassiques ayant subi une évolution chimique. La dominance du feldspath potassique monoclinique, même dans les environnements pegmatitiques, indique qu'un ou plusieurs processus firent entrave à l'ordonnance Al/Si (e.g., taux de refroidissement, composition du fluide et/ou de la roche). Cependant, d'une façon locale, le développement de feldspath potassique triclinique domine là où l'intéraction entre le fluide et la roche fut intense (e.g., dans les greisens), reflétant ainsi une altération à des températures atteignant $450^{\circ} \mathrm{C}$. Le dosage $\delta^{18} \mathrm{O}$ des minéraux prélevés dans les pegmatites reflète des conditions de déséquilibre reliées à divers degrés d'intéraction entre le fluide et la roche après leur cristallisation. La valeur calculée $\delta^{18} \mathrm{O}_{\text {nuide }}$ (pour la plupart 5-10\%) indique un réservoir de fluide à dominance magmatique; le système fut infiltré par des fluides aussi bien enrichis (jusqu'à $+18 \%$ ) qu'appauvris (jusqu'à $<+4 \%$ ), ce qui indique qu'un mélange de fluides se produisit à l'échelle locale.

[Traduit par le joumal]

*Present address: President's Office, University of Victoria, P.O. Box

1700, Victoria, British Columbia V8W 2Y2, Canada 


\section{INTRODUCTION}

The role of fluids during the terminal stages of intrusion, solidification and cooling of igneous complexes has been examined over the past few decades by, among others, H.P. Taylor and coworkers (summaries in Taylor, 1968, 1978, 1988; Taylor and Sheppard, 1986). These investigators have demonstrated the variety of source reservoirs for fluids and the influence they have in terms of isotopic equilibria among the mineral constituents. The fact that fluids played a role in the late-stage evolution of the Upper Devonian, peraluminous South Mountain Batholith of Nova Scotia (Fig. 1) is indicated by the presence of locally abundant pegmatites, variable types of alteration (cf. Charest, 1976; Charest et al., 1985; Corey, 1988; Kontak and Corey, 1988; Logothetis, 1985) and local concentrations of granitophile elements in mineralized pegmatites and greisens (cf. Chatterjee $e t$ al., 1985a, 1985b; Chatterjee and Strong, 1984; O'Reilly et al., 1982).

In an earlier paper, Kontak et al. (1988) discussed the geochemical and oxygen isotopic evolution of the South Mountain Batholith using a suite of samples that is representative of its progression from the early to late stages of differentiation. Continuity of whole-rock geochemical trends for granodiorite through late-stage leucogranite units was interpreted to reflect the dominance of crystal-melt equilibria during progressive fractional crystallization involving the major silicate phases and accessory minerals (see also Longstaffe et al., 1980). However, more evolved leucogranites (designated leucogranites II; Kontak et al., 1988) associated with pegmatite occurrences were found to have chemical signatures, particularly in their rare-earthelement (REE) patterns, indicative of a relatively more important role of fluid equilibria in their evolution. Whole-rock oxygen isotopic data were found to indicate a uniform composition for the granites of ca. $10.6 \pm 0.5 \%(n=14)$, regardless of proximity to the contact with sedimentary rocks of the flyschoid Meguma Group or degree of differentiation (e.g., $\mathrm{K} / \mathrm{Rb}$ or wt. \% $\mathrm{SiO}_{2}$ ). However, disequilibrium oxygen isotope fractionation between quartz and feldspar in pegmatites was interpreted to indicate variable re-equilibration with mostly late-stage, cooling magmatic fluids. There was some suggestion, however, that additional fluids of metamorphic and meteoric origin were also involved in the late-stage evolution of the batholith. For example,

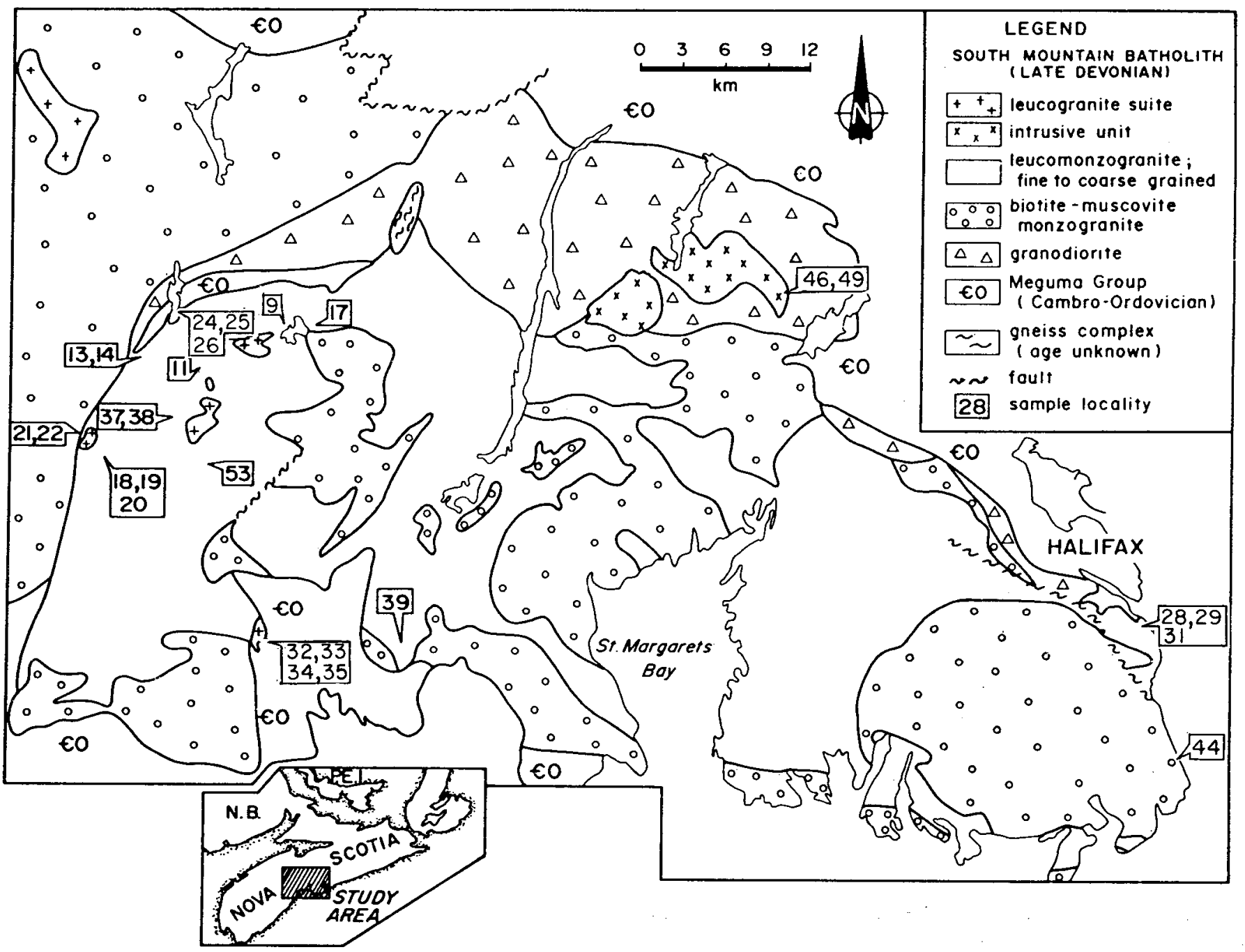

Fig. 1. Simplified geological map of the eastern part of the South Mountain Batholith (modified after MacDonald et al., 1987) showing sample locations. 
a whole-rock oxygen isotopic signature of $3.6 \%$ for an Elvan dyke rock at the Tumer tin prospect was interpreted to indicate infiltration of an ${ }^{18} \mathrm{O}$-depleted fluid at this locality, whereas involvement of an ${ }^{18} \mathrm{O}$-enriched fluid was suggested by isotopic analyses of quartz from a greisen near Herring Cove.

In this paper, further geochemical and oxygen isotope data are presented for mineral phases (quartz, feldspar, muscovite, garnet, tourmaline) from pegmatites and greisens within the eastern part of the South Mountain Batholith (Fig. 1). We have concentrated our efforts in areas underlain by pegmatites and one welldeveloped greisen in order to more closely examine the isotopic and geochemical nature of fluids in the terminal stage of batholith evolution. Analyses of REE, compatible (Ba, $\mathrm{Sr}, \mathrm{Eu})$ and incompatible ( $\mathrm{Li}, \mathrm{Cs}, \mathrm{Rb}$ ) elements in feldspars and muscovites are employed to test for the relative roles of crystal fractionation and evolved fluids. The stable isotopic systematics of the principal mineralized centres (e.g., East Kemptville) are the focus of other work (Kontak, 1988a) and, therefore, mineralization sensu stricto is not discussed herein. In addition to the isotopic and geochemical data, the degree of $\mathrm{Al}-\mathrm{Si}$ order in alkali feldspar has been determined in order to provide further information on the thermal evolution of the areas examined.

\section{GEOLOGICAL SETTING, SAMPLE LOCALITIES AND DESCRIPTIONS}

The regional geological setting of the area of interest is discussed in detail by Kontak et al. (1988), MacDonald and Horne (1988), MacDonald et al. (1987) and O'Reilly et al. (1982), to which the reader is referred for more detailed discussion of the geology. The sample localities (Fig. 1) remain the same as in our earlier study, but additional material has been analyzed from several localities (Table 1). A somewhat simplified classification of the material is provided in Table 1, with the site of interest described as granite (monzogranite, leucogranite), pegmatite or greisen. Both the samples reported on earlier (Kontak et al., 1988) and the new material are listed in Table 1 in order to provide a complete data set for later discussion. Pertinent aspects of the material used in the present investigation are summarized below.

\section{Whole-rock samples}

A whole-rock granite sample (35) from Long Lake was analyzed. This is a fine-grained, muscovite-bearing leucogranite collected from drill core at the main mineralized showing. It is identical to sample 33 described in Kontak et al. (1988). The major- and trace-element (including REE) chemistry of this typeI leucogranite (see Kontak et al., 1988) is provided in our previous publication. A quartz-feldspar mineral pair from the $\mathrm{K}$ feldspar megacrystic biotite monzogranite (11-1) that hosts the Walker molybdenum showing also was analyzed.

\section{Greisens}

A single area of intense greisen development at Sandwich Point, just north of Herring Cove, is represented by samples 28 and 29. The area is fully described by MacDonald and O'Reilly (1989) and is of particular interest because of the presence of anomalous gold values in sulphide-bearing greisens. Sample 28, a muscovite-quartztfeldspar intergrowth, represents intense greisenization of the local two-mica monzogranite (represented by sample 29) in the form of a $1 \mathrm{~m}$ wide pod. Nearby, two samples of greisen veins were also collected. Sample 29A represents a replacement greisen in which the precursor monzogranite has been intensely altered owing to infiltration of fluids along a well developed system of fractures. The sample contains coarse (1-2 $\mathrm{cm}$ ) clots of muscovite disseminated throughout the altered precursor. In contrast, sample 29B represents a vein infilling consisting of quartz-feldspar-muscovite \pm tourmaline \pm sulphides. This type of occurrence contains the anomalous gold values described by MacDonald and O'Reilly (1989).

\section{Pegmatites}

Several pegmatite localities are represented, most of these occurring in the vicinity of New Ross (Fig. 1). These localities are all very similar, with local pegmatitic segregations associated with fine- to medium-grained muscovite \pm biotite leucogranite. The following additional points are noted for some individual localities.

(1) Walker molybdenum: 11 - banded aplite-pegmatite with finely disseminated molybdenite mineralization throughout.

(2) Long Lake: 34B - coarse (cm-scale) quartz vein-segregation with abundant molybdenite flakes intergrown with milky white quartz. 32 - coarse (3-5 cm) K-feldspar grains grown on a fracture surface transecting greisenized leucogranite (see fig. 9 of O'Reilly et al., 1982).

(3) Morley's pegmatite: 36 - coarse $(4-5 \mathrm{~cm})$ rosettes of muscovite intergrown with quartz occur within feldspar-rich domains of the pegmatite. Muscovite rosettes probably postdated the feldspar.

(4) Pockwock: 46-2 - this sample is itself not a pegmatite, but is included under this heading because of its association with pegmatites. The sample represents an occurrence of metasomatic garnet found in fine-grained aplitic dykes and two-mica monzogranite. The nature of the occurrence has been described in detail by Kontak and Corey (1988), in particular the sample from which the garnet was separated for oxygen isotopic analysis.

\section{ANALYTICAL TECHNIQUES}

Quartz, feldspar, garnet and tourmaline separates were prepared by first pulverizing samples to a coarse crush $(<0.5-1 \mathrm{~cm})$, followed by sieving and hand-picking. The high-grade concentrates were further comminuted (-20+40 mesh) and hand-picked under a binocular microscope to ensure high-quality concentrates. Mineral separates were subsequently cleaned using distilled water in an ultrasonic bath and then dried and stored in plastic vials. The feldspar fractions were crushed to -200 mesh using a steel shatter box in preparation for additional chemical analysis. Muscovite separates $(-40+80$ mesh) were prepared using conventional techniques of separation (i.e., magnetic separator and heavy liquids). 
Table 1. Sample descriptions and oxygen isotope data, South Mountain Batholith.

\begin{tabular}{|c|c|c|c|c|c|c|c|c|c|}
\hline Sample & Rock Type & Location & wr & $\mathrm{qtz}$ & $\mathbf{k f}$ & alb & $\mathrm{ms}$ & gar & tour \\
\hline 9 & monzogranite & Lower Canoe Lake & 11.1 & & 11.0 & & & & \\
\hline 11 & pegmatite & Walker moly & & 8.9 & 9.8 & & 8.2 & & \\
\hline $11-1$ & monzogranite & Walker moly & & 11.5 & 123 & & & & \\
\hline $11-2$ & leucogranite & Walker moly & 10.0 & & & & & & \\
\hline 13 & Elvan dyke & Turner Tin & 3.6 & & & & & & \\
\hline 14 & monzogranite & Turner Tin & 9.5 & & & & & & \\
\hline $17-1$ & leucogranite & Lower Canoe Lake & 10.8 & & & & & & \\
\hline $17-2$ & leucogranite & Lower Canoe Lake & 10.4 & & & & & & \\
\hline 18 & pegmatite & Keddy's tin & & 17.6 & 10.6 & & & & \\
\hline 19 & pegmatite & Keddy's tin & & 11.9 & 11.0 & & & & \\
\hline 20 & leucogranite & Keddy's tin & 10.7 & & & & & & \\
\hline 21 & leucogranite & Reeve's tin & 11.4 & & & & & & \\
\hline $22 \mathrm{~B}$ & pegmatite & Reeve's tin & & 15.5 & 9.7 & & & & \\
\hline $22 \mathrm{C}$ & pegmatite & Reeve's tin & & 11.4 & 11.4 & & & & \\
\hline 24 & pegmatite & Grassy Brook tin & & 10.3 & 10.1 & & & & \\
\hline 25 & pegmatite & Grassy Brook tin & & 11.4 & 8.9 & & & & \\
\hline $26-1$ & leucogranite & Grassy Brook tin & 10.9 & & & & & & \\
\hline $26-2$ & leucogranite & Grassy Brook tin & 10.0 & & & & & & \\
\hline 28 & greisen & Herring Cove & & 18.2 & & & 12.0 & & \\
\hline 29 & monzogranite & Herring Cove & & 12.2 & & & & & \\
\hline $29 \mathrm{~A}$ & greisen & Herring Cove & & 13.9 & 15.1 & & 108 & & \\
\hline 29B & greisen & Herring Cove & & 128 & 8.1 & & & & \\
\hline 31 & monzogranite & Herring Cove & 11.0 & & & & & & \\
\hline 32 & pegmatite & Long Lake & & 11.9 & & & & & \\
\hline 33 & leucogranite & Long Lake & 10.4 & & & & & & \\
\hline 34-1 & pegmatite & Long Lake & & 10.6 & 11.0 & & & & \\
\hline $34 \mathrm{~A}$ & pegmatite & Long Lake & & 10.8 & 11.0 & & & & \\
\hline $34 \mathrm{~B}$ & pegmatite & Long Lake & & 128 & & & & & \\
\hline 35 & leucogranite & Chester & 11.0 & & & & & & \\
\hline 36 & pegmatite & Moreley's pegmatite & & 8.9 & & & 9.3 & & \\
\hline $36 \mathrm{~A}$ & pegmatite & Moreley's pegmatite & & 10.9 & & 13.2 & & & \\
\hline 36B & pegmatite & Moreley's pegmatite & & & & 10.2 & & & \\
\hline $37 \mathrm{~A}$ & leucogranite & Moreley's pegmatite & 11.3 & & & & & & \\
\hline 38 & pegmatite & Moreley's pegmatite & & 11.6 & 10.0 & & & & \\
\hline 39 & leucogranite & Moreley's pegmatite & 9.9 & & & & & & \\
\hline $44 B$ & pegmatite & Portugese Cove & & 126 & 12.2 & & & & 10.4 \\
\hline $46-2$ & pegmatite & Pockwock & & 120 & 11.6 & & & 9.2 & \\
\hline 49 & pegmatite & Pockwock & & 11.3 & 11.6 & & 8.8 & & \\
\hline 53 & monzogranite & New Ross & 11.0 & & & & & & \\
\hline
\end{tabular}

Note: except for samples 17-1, 17-2 the leucogranites occur as aplitic segregations within areas underlain by mixed pegmatite/leucogranite. Numbers in bold type represent analyses determined in this study. Abbreviations: wr - whole rock, qtz - quartz, kf - K-feldspar, alb - albite, ms - muscovite, gar - garnet, tour - tourmaline.

Major element analyses of feldspar concentrates were performed by G. Andrews at the Department of Earth Sciences, Memorial University, Newfoundland, employing wet-chemical digestion combined with Atomic Absorption Spectrometry. Trace element concentrations in feldspar and muscovite separates were obtained using the inductively coupled plasma mass spectrometry [ICP-MS; see Strong and Longerich (1985) for general discussion] facilities at Memorial University. Details of the procedures, analytical precision and accuracy are fully described by Longerich et al. (1990) and Jenner et al. (1990).

Oxygen isotopic compositions were determined on one wholerock and 27 mineral separates at the University of Saskatchewan employing conventional procedures for the isotopic analysis of silicates (Clayton and Mayeda, 1963). Isotopic data are reported as $\delta^{18} \mathrm{O}$ values in per mil $(\%)$ relative to Standard Mean Ocean Water (SMOW) based on analysis of the NBS-28 laboratory standard. The overall reproduceability of $\delta^{18} \mathrm{O}$ values is \pm 0.18 $\%$ (2 sigma).

$\mathrm{X}$-ray powder diffractograms of pulverized $\mathrm{K}$-feldspar separates were performed using an automated Philips X-ray powder diffraction system at Memorial University, Newfoundland. Conditions employed in this study were $\mathrm{CuK} \alpha$ radiation and a chart recorder speed of $1^{\circ} 28 /$ minute. A more detailed analysis of the structural state of these samples, based on cell parameters, will be presented elsewhere.

\section{ANALYTICAL RESULTS}

\section{Mineral chemistry}

Muscovite separates from three pegmatites $(11,36,49)$ and one greisen locality (28) were analyzed for their trace element contents (Table 2). Collectively the data show large variations in elements such as $\mathrm{Li}$ (209 to $955 \mathrm{ppm}), \mathrm{Rb}$ (848 to $4619 \mathrm{ppm}), \mathrm{Zr}$ (4.9 to $101 \mathrm{ppm}$ ), Cs (69 to $223 \mathrm{ppm}$ ) and $\mathrm{Hf}$ (0.7 to $15 \mathrm{ppm}$ ). Similarly, broad ranges are also observed for elemental ratios, for example $\mathrm{Rb} / \mathrm{Sr}, \mathrm{Ba} / \mathrm{Sr}, \mathrm{U} / \mathrm{Th}$ and $\mathrm{Zr} / \mathrm{Hf}$ (see Table 2). Such variations are typical for white micas within the South Mountain Batholith, based on previous studies (Ham and Kontak, 1988), although it is not always clear how much of the variation is 
Table 2. Trace element geochemistry of muscovites, South Mountain Batholith.

\begin{tabular}{|c|c|c|c|c|}
\hline$\#$ & 11 & 28 & 36 & 49 \\
\hline \multicolumn{5}{|c|}{ Trace Elements (ppm): } \\
\hline $\mathrm{Li}$ & 955 & 209 & 603 & 265 \\
\hline $\mathrm{Rb}$ & 1497 & 848 & 4619 & 1556 \\
\hline Sr & 5.3 & 4.8 & 11.4 & 2.2 \\
\hline$Y$ & 0.1 & 5.0 & 2.6 & 0.1 \\
\hline $\mathrm{Zr}$ & 4.9 & 36.2 & 101 & 5.3 \\
\hline Cs & 90 & 34.7 & 227 & 69.9 \\
\hline $\mathrm{Ba}$ & 12 & 223 & 3.1 & 5.9 \\
\hline Th & 0.1 & 4.7 & 0.7 & 0.1 \\
\hline $\mathrm{U}$ & 10.4 & 11.1 & 4.1 & 0.6 \\
\hline $\mathrm{Hf}$ & 0.7 & 2.0 & 15 & 1.3 \\
\hline
\end{tabular}

Elemental Ratios:

$\begin{array}{lcccc}\mathrm{Rb} / \mathrm{Sr} & 282 & 176 & 405 & 707 \\ \mathrm{Ba} / \mathrm{Sr} & 2.2 & 46 & 0.2 & 2.6 \\ \mathrm{Li} / \mathrm{Cs} & 10.6 & 6.0 & 2.6 & 3.7 \\ \mathrm{U} / \mathrm{Th} & 104 & 2.3 & 5.8 & 6.0 \\ \mathrm{Zr} / \mathrm{Hf} & 7.0 & 18 & 6.7 & 4.0\end{array}$

Rare Earth Elements (ppm):

$\begin{array}{llcll}\text { La } & 0.091 & 9.068 & 0.085 & 0.101 \\ \text { Ce } & 0.11 & 18.83 & 0.131 & 0.232 \\ \text { Pr } & 0.020 & 2.06 & 0.017 & 0.023 \\ \text { Nd } & 0.081 & 7.57 & 0.111 & 0.081 \\ \text { Sm } & 0.031 & 1.809 & 0.111 & 0.022 \\ \text { Eu } & 0.005 & 0.051 & 0.014 & 0.082 \\ \text { Gd } & 0.035 & 1.466 & 0.256 & 0.024 \\ \text { Tb } & 0.006 & 0.275 & 0.088 & 0.005 \\ \text { Dy } & 0.035 & 1.426 & 0.664 & 0.032 \\ \text { Ho } & 0.004 & 0.219 & 0.119 & 0.004 \\ \text { Er } & 0.006 & 0.523 & 0.587 & 0.014 \\ \text { Tm } & 0.002 & 0.077 & 0.075 & 0.003 \\ \text { Yb } & 0.007 & 0.490 & 0.620 & 0.019 \\ \text { Lu } & 0.001 & 0.069 & 0.076 & 0.003\end{array}$

attributable to parameters such as different precursors in the case of greisens (e.g., granodiorite versus leucomonzogranite), crystal-chemical controls or presence of micro-inclusions. For example, the anomalous enrichment of $\mathrm{Ba}$ in greisen sample 28 is noted, as well as the elevated $\mathrm{Zr}$ and $\mathrm{Hf}$ contents in muscovite of pegmatite sample 36.

Chondrite-normalized REE plots for muscovite separates are shown in Figure 2. Sample 28 shows the largest absolute enrichment with an $\mathrm{La}_{\mathrm{N}}$ value of 30 , a strongly fractionated pattem [(La/ $\left.\mathrm{Lu})_{\mathrm{N}}=13.4\right]$ and a strong negative Eu anomaly $\left(\mathrm{Eu} / \mathrm{Eu}^{*}=0.10\right)$. This pattern is strikingly similar, both with respect to its shape and normalized values, to REE patterns obtained for muscovite from monzogranite (Ham and Kontak, 1988). In contrast, the three remaining muscovites from pegmatite occurrences are depleted in terms of absolute abundance with $\mathrm{La}_{\mathrm{N}}$ values of about 0.3 . In two samples $(11,49)$ the patterns are fractionated, with $(\mathrm{La} / \mathrm{Lu})_{\mathrm{N}}=9.3$ and 3.4, respectively, but their Eu anomalies are variable, one being negative and the other positive $\left(\mathrm{Eu} / \mathrm{Eu}^{*}=\right.$ 0.46 and 11.0, respectively). In contrast, sample 36 shows an enrichment in the heavy REE, such that $(\mathrm{La} / \mathrm{Lu})_{\mathrm{N}}=0.11$. This latter feature, in combination with elevated $\mathrm{Zr}$ and $\mathrm{Hf}$ contents of this sample (Table 2), suggests contamination by zircon inclusions (e.g., McLellan, 1989). In our earlier paper (Kontak et al.,

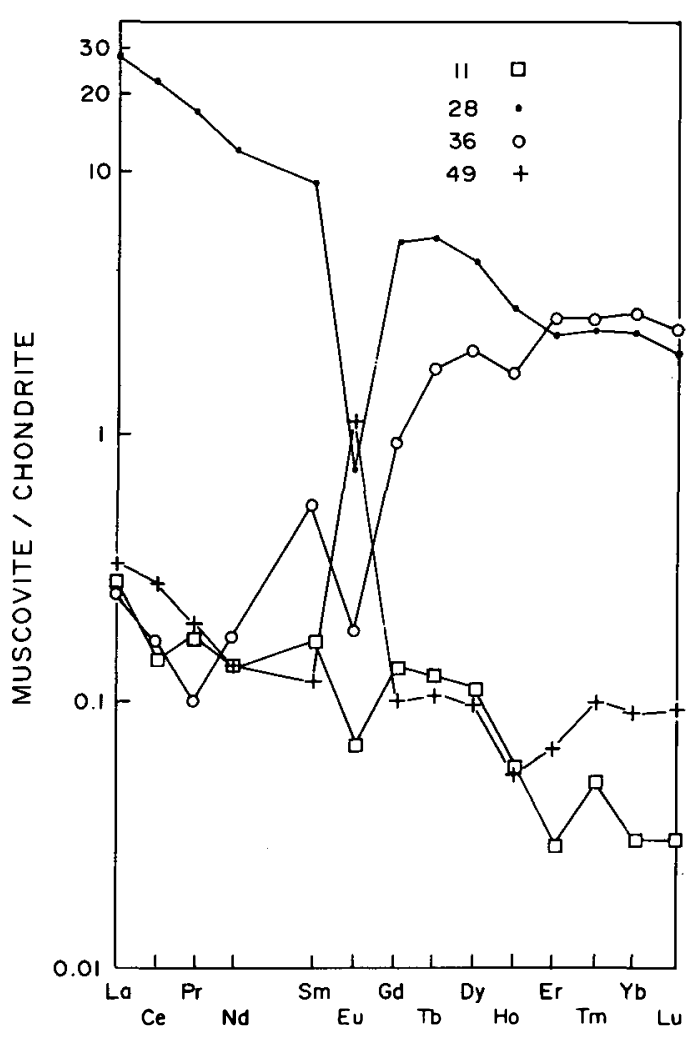

Fig. 2. Chondrite-normalized REE profiles for muscovite samples, South Mountain Batholith.

1988), we suggested that a similar pattern may have resulted from REE enrichment due to anionic complexes (e.g., F) in late-stage magmatic fluids. Clearly, the more complete set of analyses would favor enrichment due to incorporation of an accessory mineral such as zircon.

The major- and trace-element chemistries of 14 samples of $\mathrm{K}$ feldspar and three of $\mathrm{Na}$-feldspar are presented in Table 3. Based on nature of occurrence and bulk composition, the K-feldspar population can be subdivided into three groupings, namely: (1) granitic affinity $(9,29 \mathrm{~B}, 31)$ with bulk compositon $\sim \mathrm{Or}_{60}$, (2) pegmatitic affinity $(11,18,19,22 \mathrm{~B}, 22 \mathrm{C}, 24,25 \mathrm{~B}, 34 \mathrm{~A}, 38,49 \mathrm{~K})$ with bulk composition $\sim \mathrm{Or}_{70-79}$, and (3) metasomatic affinity (32) with bulk composition $\mathrm{Or}_{93}$. The second group can be further subdivided on the basis of covariation of $R b$ versus Sr. Samples $18,19,22 \mathrm{~B}$ and 22C (group 2.2) are characterized by their elevated $\mathrm{Rb} / \mathrm{Sr}$ values (Figs. 3, 4, Table 3). The K-feldspar populations examined in this study correspond to the broad groupings defined for the South Mountain Batholith based on the covariation of $\mathrm{Ba}$ and $\mathrm{Sr}$ versus $\mathrm{Rb}$ (Fig. 3; Kontak, 1988b; Kontak and Strong, 1988).

Chondrite-normalized REE plots for the K-feldspar separates are shown in Figure 5. Group $1 \mathrm{~K}$-feldspar (Fig. 5A) is characterized by elevated absolute abundances compared to the other groups (Table 3, Fig. 4), strongly fractionated patterns $\left[(\mathrm{La} / \mathrm{Yb})_{\mathrm{N}}\right.$ $=17.1-28.7]$ and positive Eu anomalies $\left(\mathrm{Eu} / \mathrm{Eu}^{*}=4.1-8.0\right)$ for two of the samples. Sample 29B is noted for its lack of an Eu anomaly $\left(\mathrm{Eu}^{\mathrm{Eu}} \mathrm{u}^{*}=0.94\right)$. Group $2.1 \mathrm{~K}$-feldspar has lower absolute abundances of REE (Figs. 4, 5B, 5C, Table 3) compared 
Table 3. Geochemistry of feldspars, South Mountain Batholith.

\begin{tabular}{|c|c|c|c|c|c|c|c|c|c|c|c|c|c|c|c|c|c|}
\hline$\#$ & 9 & 11 & 18 & 19 & 22B & $22 \mathrm{C}$ & 24 & $25 \mathrm{~B}$ & $29 B$ & 31 & 32 & $34 \mathrm{~A}$ & $36 \mathrm{~A}$ & $36 \mathrm{~B}$ & 38 & $49 \mathrm{~K}$ & $49 A$ \\
\hline \multicolumn{18}{|c|}{ Major Oxide Elements (wL. \%): } \\
\hline $\mathrm{SiO}_{2}$ & 65.70 & 63.30 & 63.30 & 63.80 & 63.10 & 63.10 & 62.90 & 64.00 & 65.10 & 64.70 & 63.30 & 63.80 & 64.70 & 65.43 & 63.50 & 64.30 & 67.00 \\
\hline $\mathrm{Al}_{2} \mathrm{O}_{3}$ & 18.70 & 19.70 & 19.30 & 19.40 & 19.10 & 19.00 & 19.20 & 19.40 & 18.20 & 18.80 & 18.20 & 18.70 & 20.00 & 19.90 & 19.40 & 19.20 & 20.50 \\
\hline $\mathrm{Fe}_{2} \mathrm{O}_{3}$ & 0.20 & 0.12 & 0.18 & 0.19 & 0.06 & 0.07 & 0.18 & 0.15 & 0.16 & 0.17 & 0.52 & 0.21 & 0.13 & 0.13 & 0.18 & 0.12 & 0.09 \\
\hline $\mathrm{Na}_{2} \mathrm{O}$ & 4.34 & 3.24 & 2.40 & 2.93 & 2.24 & 3.34 & 2.34 & 3.10 & 3.66 & 4.02 & 0.54 & 2.88 & 9.74 & 9.70 & 3.03 & 3.85 & 10.84 \\
\hline $\mathrm{K}_{2} \mathrm{O}$ & 9.55 & 12.27 & 12.52 & 12.28 & 13.14 & 11.58 & 13.49 & 12.27 & 10.76 & 10.39 & 15.10 & 12.35 & 1.43 & 1.36 & 12.00 & 11.16 & 0.63 \\
\hline $\mathrm{CaO}$ & 0.38 & 0.18 & 0.08 & 0.10 & 0.10 & 0.20 & 0.12 & 0.22 & 0.36 & 0.30 & 0.42 & 0.32 & 0.68 & 0.74 & 0.58 & 0.10 & 0.58 \\
\hline LOI & 0.41 & 0.46 & 0.54 & 0.36 & 0.42 & 0.23 & 0.38 & 0.42 & 0.41 & 0.43 & 0.83 & 0.87 & 0.72 & 0.79 & 0.73 & 0.38 & 0.41 \\
\hline$\%$ or & 58.0 & 70.7 & 77.1 & 73.0 & 79.0 & 68.1 & 78.7 & 71.5 & 64.7 & 62.0 & 92.8 & 72.7 & 8.5 & 8.1 & 70.2 & 67.1 & 3.6 \\
\hline \multicolumn{18}{|c|}{ Trace Elements (ppm): } \\
\hline $\mathrm{Li}$ & 14.6 & 30.5 & 35 & 8.3 & 119 & 32.1 & 10.1 & 7.9 & 12.9 & 13.2 & 123 & 8.1 & 6.4 & 5.8 & 11.8 & 15.2 & 17.2 \\
\hline Ga & 35 & 46.9 & 54 & 44.6 & 47.4 & 40.6 & 67 & 47.3 & 22.3 & 29 & 35.3 & 26.4 & 56.3 & 57.8 & 46.3 & 37.8 & 49.6 \\
\hline $\mathbf{R b}$ & 481 & 934 & 1925 & 1807 & 6200 & 1759 & 1133 & 897 & 523 & 443 & 1023 & 445 & 106 & 104 & 1039 & 56.4 & 44.8 \\
\hline $\mathrm{Sr}$ & 101 & 7.6 & 2.4 & 3.5 & 2.9 & 6.6 & 8.6 & 9.1 & 28.1 & 71.5 & 26.7 & 25.5 & 10.2 & 11.4 & 16.5 & 23.4 & 29.6 \\
\hline $\mathrm{Ba}$ & 1298 & 68.5 & 29 & 21.8 & 21.3 & 14.9 & 39.8 & 39.5 & 432 & 436 & 258 & 103 & 14.5 & 16.3 & 69.8 & 103 & 11.6 \\
\hline $\mathrm{Pb}$ & 55 & 54.3 & 9.4 & 10.1 & 3.2 & 6.8 & 37.2 & 29.5 & 15.2 & 59.5 & 25.7 & 50.1 & 8.7 & 7.3 & 14.6 & 35 & 21.1 \\
\hline Th & 1.8 & 0.2 & 0.1 & ND & ND & ND & ND & ND & 2.1 & 0.9 & 1.3 & 0.3 & 0.1 & 0.6 & 0 & 0.4 & 0 \\
\hline $\mathrm{U}$ & 3.2 & 5.2 & 1.7 & 2.5 & 0.2 & 0.6 & 2.2 & 2.4 & 2.0 & 0.7 & 14.5 & 5.3 & 0.7 & 0.6 & 0.6 & 4.9 & 3.6 \\
\hline $\mathrm{Y}$ & 1.4 & 0.7 & 0.1 & ND & 0.2 & 0.2 & 0.4 & 0.7 & 2.7 & 1.3 & 4.5 & 1.3 & 1.5 & 2.4 & 1.0 & 1.8 & 0.8 \\
\hline $\mathrm{Zr}$ & 5.3 & 1.5 & 3.5 & 0.3 & 0.2 & 1.0 & 0.4 & 0.3 & 11.6 & 7.8 & 8.4 & 2.6 & 0.6 & 1.6 & 1.6 & 5.6 & 0 \\
\hline Cs & 9.4 & 11.6 & 14 & 11.4 & 35.8 & 10.0 & 11.1 & 8.5 & 4.7 & 5.8 & 21.3 & 9.4 & 2.5 & 2.1 & 21.2 & 7.2 & 1.3 \\
\hline \multicolumn{18}{|c|}{ Rare Earth Elements (ppm): } \\
\hline La & 6.48 & 0.54 & 0.13 & 0.11 & 0.28 & 0.15 & 0.43 & 0.32 & 9.13 & 3.70 & 3.36 & 1.41 & 0.36 & 0.52 & 0.43 & 3.36 & 3.35 \\
\hline $\mathrm{Ce}$ & 10.72 & 1.01 & 0.22 & 0.18 & 0.40 & 0.25 & 0.95 & 0.63 & 19.0 & 6.70 & 8.73 & 3.10 & 0.83 & 1.63 & 1.14 & 4.66 & 6.67 \\
\hline $\mathrm{Pr}$ & 1.05 & 0.09 & 0.04 & 0.02 & 0.05 & 0.02 & 0.10 & 0.09 & 1.87 & 0.64 & 0.92 & 0.35 & 0.14 & 0.28 & 0.16 & 0.75 & 0.74 \\
\hline Nd & 3.04 & 0.33 & 0.14 & 0.01 & 0.19 & 0.13 & 0.36 & 0.30 & 6.37 & 2.09 & 3.58 & 1.33 & 0.61 & 1.41 & 0.78 & 2.65 & 2.54 \\
\hline $\mathrm{Sm}$ & 0.81 & 0.14 & 0.06 & 0.01 & 0.05 & 0.01 & 0.18 & 0.15 & 1.57 & 0.53 & 1.04 & 0.39 & 0.35 & 0.64 & 0.35 & 0.77 & 0.64 \\
\hline Eu & 1.60 & ND & ND & ND & ND & ND & ND & 0.02 & 0.39 & 0.54 & 0.16 & 0.14 & 0.04 & 0.04 & 0.04 & 0.23 & 0.09 \\
\hline $\mathrm{Gd}$ & 0.46 & 0.10 & 0.02 & ND & ND & ND & 0.14 & 0.13 & 1.04 & 0.31 & 0.64 & 0.26 & 0.28 & 0.39 & 0.18 & 0.50 & 0.31 \\
\hline $\mathrm{Tb}$ & 0.05 & 0.01 & ND & ND & ND & ND & 0.01 & 0.02 & 0.10 & 0.03 & 0.07 & 0.03 & 0.06 & 0.07 & 0.03 & 0.05 & 0.03 \\
\hline Dy & 0.28 & 0.11 & .05 & ND & 0.02 & 0.01 & 0.06 & 0.10 & 0.63 & 0.20 & 0.58 & 0.22 & 0.27 & 0.37 & 0.16 & 0.38 & 0.19 \\
\hline Ho & 0.03 & 0.01 & ND & ND & ND & ND & ND & 0.01 & 0.07 & 0.03 & 0.09 & 0.04 & 0.04 & 0.04 & 0.03 & 0.06 & 0.02 \\
\hline Er & 0.12 & 0.05 & 0.01 & ND & 0.05 & 0.02 & 0.01 & 0.02 & 0.16 & 0.10 & 0.31 & 0.12 & 0.07 & 0.13 & 0.10 & 0.17 & 0.13 \\
\hline $\mathrm{Yb}$ & 0.25 & 0.12 & 0.05 & 0.09 & 0.19 & 0.12 & 0.03 & 0.02 & 0.21 & 0.13 & 0.37 & 0.17 & 0.12 & 0.16 & 0.15 & 0.29 & 0.15 \\
\hline Lu & 0.03 & 0.01 & 0.01 & ND & ND & ND & ND & ND & 0.03 & 0.01 & 0.05 & 0.02 & 0.01 & 0.01 & 0.01 & 0.04 & 0.01 \\
\hline $\mathrm{Rb} / \mathrm{Sr}$ & 4.7 & 122 & 802 & 516 & 2137 & 266 & 131 & 98 & 18.6 & 6.1 & 38.3 & 17.4 & 10.3 & 9.1 & 63 & 24.1 & 1.5 \\
\hline $\mathrm{Eu} / \mathrm{Eu}{ }^{\circ}$ & 8.07 & & 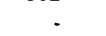 & - & - & & . & 0.44 & 0.94 & 4.10 & 0.60 & 1.35 & 0.39 & 0.24 & 0.48 & 1.14 & 0.62 \\
\hline$(\mathrm{La} / \mathrm{Yb})_{N}$ & 17.1 & 2.76 & 1.71 & 0.34 & 0.88 & 0.82 & 1.36 & 10.5 & 28.7 & 18.7 & 5.99 & 5.47 & 1.98 & 2.14 & 1.89 & 7.54 & 14.7 \\
\hline LREE & 24.9 & 2.55 & 0.73 & 0.32 & 1.23 & 0.71 & 2.27 & 1.81 & 40.5 & 15.01 & 19.9 & 7.58 & 3.18 & 5.69 & 3.56 & 13.9 & 14.8 \\
\hline
\end{tabular}

$\mathrm{ND}=$ not detected 


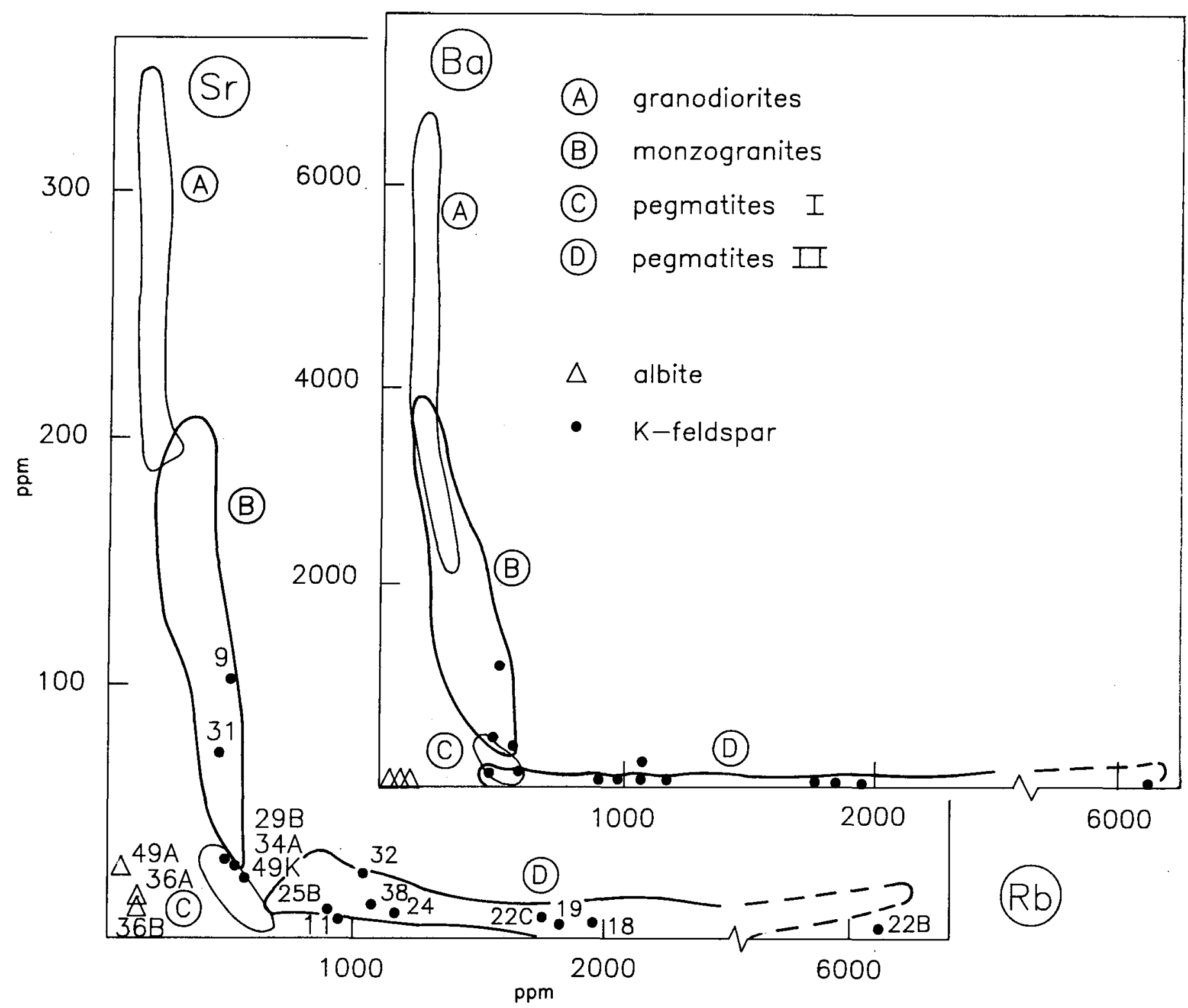

Fig. 3. Sr and Ba versus Rb bivariate plots (contents in ppm) for alkali feldspars from the South Mountain Batholith. The fields labelled A, B, C and $\mathrm{D}$ are based on the variation of these elements in alkali feldspars from the appropriate rock units in the eastern part of the South Mountain Batholith [based on work of Kontak (1988b) and Kontak and Strong (1988)]. Note the break in the horizontal scale for Rb.

to group 1, is less fractionated [ $\left.(\mathrm{La} / \mathrm{Yb})_{\mathrm{N}}=1.36-10.5\right]$, and has either positive $(34 \mathrm{~A}, 49 \mathrm{~K})$ or negative $(38,11,24,25) \mathrm{Eu}$ anomalies. Within group 2.1, there is a gradual decrease in absolute REE abundance that corresponds to increasing $\mathrm{Rb} / \mathrm{Sr}$ values (Fig. 4), such that samples $34 \mathrm{~A}$ and $49 \mathrm{~K}$ are less fractionated (i.e., with respect to $\mathrm{Rb} / \mathrm{Sr}$ values) compared to $24,25 \mathrm{~B}, 11$ and 38.

Group $2.2 \mathrm{~K}$-feldspar is characterized by still lower overall abundances of REE (Figs. 4, 5C), a less fractionated pattern [0.34 $\left.<(\mathrm{La} / \mathrm{Yb})_{\mathrm{N}}<1.71\right]$, and probable negative Eu anomaly. The erratic nature of some of the profiles in Figure 5C is due in part to the low REE abundances (i.e., $<0.2-0.3$ chondritic values), which approach limits of analytical detection. With respect to the REE contents, the single group $3 \mathrm{~K}$-feldspar is similar to group 1 samples in terms of absolute abundances and its chondrite- normalized pattern $\left[(\mathrm{La} / \mathrm{Yb})_{\mathrm{N}}=5.9\right.$ (Fig. 5B)], but differs by virtue of a negative Eu anomaly $\left(\mathrm{Eu} / \mathrm{Eu}^{*}=0.6\right)$.

The three albite separates analyzed have bulk compositions of $\mathrm{Ab}_{92.96}$ and trace element compositions comparable to the $\mathrm{K}$ feldspar population, except for the notable depletion of $\mathrm{Rb}$ (Fig. 3). Chondrite-normalized REE patterns (Fig. 5D) indicate two distinct profiles. The profile for $49 \mathrm{~A}$ is somewhat similar to the pattern for $49 \mathrm{~K} \mathrm{~K}$-feldspar because it is strongly fractionated $\left[(\mathrm{La} / \mathrm{Yb})_{\mathrm{N}}=14.7\right]$, whereas samples $36 \mathrm{~A}$ and $36 \mathrm{~B}$ have similar profiles, which show a reverse trend for $\mathrm{La}-\mathrm{Sm}$ and large $\mathrm{Eu}$ anomalies $\left(\mathrm{Eu} / \mathrm{Eu}^{*}=0.24,0.39\right)$ compared to $49 \mathrm{~A}$.

\section{X-ray diffraction studies of the K-feldspar}

X-ray powder diffractograms of K-feldspar separates analyzed 


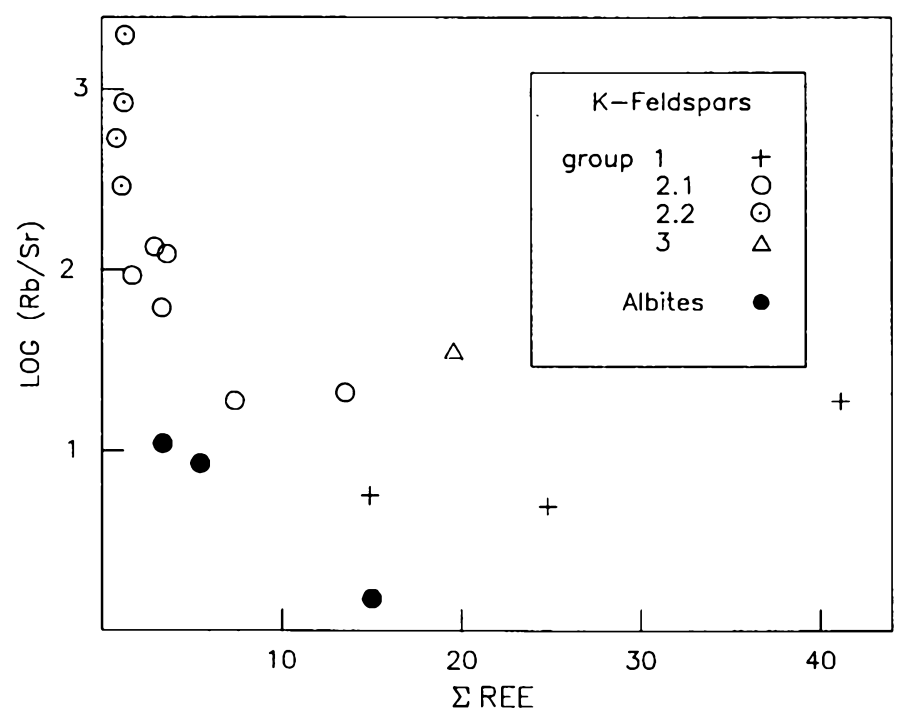

Fig. 4. Bivariate plot of $\mathrm{Rb} / \mathrm{Sr}$ (log values) versus total $\mathrm{REE}$ contents of alkali feldspars, South Mountain Batholith. The significance of the groupings $(1,2.1,2.2,3)$ is discussed in the text.

in the present investigation are shown for the critical range of $2 \theta$ values between 29 and 31 degrees (Fig. 6). The majority of the samples correspond to monoclinic structures; by analogy to more detailed studies involving cell refinements (e.g., Cerny and Chapman, 1984), petrographic observations (i.e., 2V determinations) and unpublished cell refinements, these samples correspond to orthoclase or low sanidine. However, the presence of broad-shaped profiles for the (131) ${ }_{\mathbf{K}}$ reflection (cf. Jiranek, 1982) in some samples $(11 \mathrm{~A}, 17-2,24,31,38)$ may indicate small but variable amounts of incipient development of triclinic domains. This is perhaps most evident in sample 38-1 which may contain a significant amount of intergrown triclinic $\mathrm{K}$-feldspar. However, probably the most notable feature is the overall predominance of the monoclinic structural state for pegmatitic $\mathrm{K}$-feldspars (e.g., note the sharp (131) $)_{\mathrm{K}}$ reflection for sample 22C) considering their formation in a fluid-rich environment (Parsons and Boyd, 1971; Parsons, 1977). In contrast to the aforementioned samples, development of triclinic phases occurs in samples 29B, 32 and 49, with the latter samples clearly reflecting the presence of both monoclinic and triclinic phases.

\section{Oxygen isotope data}

Results of oxygen isotopic determinations are presented in Table 1 and Figure 7. The single whole-rock analysis for sample 35 , a muscovite-bearing leucogranite, of $11.0 \%$ is similar to results presented earlier, which averaged $10.6 \pm 0.5 \%(n=14)$. Quartz separates show a broad range from 8.9 to $17.6 \%$ for the new determinations, comparable to the range reported earlier (8.9 to $18.2 \%$ ). Subdivision of the data into individual localities indicates no significant differences among the populations. A single determination on quartz from a monzogranite (11-1) gives $11.5 \%$, whereas two quartz samples from greisens have $\delta^{18} \mathrm{O}$ values of $12.8(29 \mathrm{~B})$ and $13.9 \%(29 \mathrm{~A})$, and pegmatitic quartz averages $12.4 \pm 2.3 \%(n=10)$.
Eight new K-feldspar determinations are reported and, as with quartz, there are no apparent inter-occurrence variations. The two greisen-hosted samples (29A, B) have values of 15.1 and 8.1 $\%$, respectively, whereas the granite-hosted samples $(11-1,14)$ have comparable values of 12.3 and $8.2 \%$. The four samples from pegmatitic occurrences define a smaller range with $\delta^{18} \mathrm{O}$ of $10.9 \pm 1.0 \%$. These results, like those for quartz, are broadly similar to the results reported earlier for the South Mountain Batholith. Two samples of albite from Morley's pegmatite have values $(10.3$ and $13.2 \%$ ) similar to $\mathrm{K}$-feldspar.

Two new determinations have been made on muscovite, one from the greisen locality near Herring Cove (29A) and the other from Morley's pegmatite (36). The values of 10.8 and $9.3 \%$, respectively, are similar to three analyses $(8.2,8.8,12 \%)$ reported earlier (Kontak et al., 1988). Finally, we report the results of single analyses of garnet $(9.2 \%)$ and tourmaline $(10.4$ $\%$, which represent the first results on these mineral phases in the South Mountain Batholith.

\section{DISCUSSION}

The data presented above all have bearing, albeit in different ways, on aspects of the chemical and physical evolution of the South Mountain Batholith. For example, the trace element distributions in muscovite and feldspar are a function of crystalchemical parameters during magmatic to late magmatic-pegmatitic stages, whereas the structures of the K-feldspar transcend this range and may also reflect physical conditions during the post-magmatic stage to temperatures below $400^{\circ} \mathrm{C}$. The oxygen isotope data have the potential to reveal information from the early magmatic stage to the post-magmatic stage.

\section{Implications of structural states of alkali feldspars}

The series low sanidine-orthoclase-microcline is in part a reflection of decreasing thermal conditions; hence, the presence or absence of these polymorphs provides certain constraints on the thermal evolution of the host rocks, granites or otherwise. In detail, however, other factors, including composition of the mineral phase, bulk composition of the host rock and fluid phase, pressure (i.e., strain) and cooling rate, may also exert an influence on the ultimate structural state of alkali feldspar (see Martin, 1974; Parsons and Brown, 1984).

From the diffractograms presented above (also additional unpublished data of Kontak), it is obvious that the dominant $\mathrm{K}$ feldspar polymorph is the monoclinic variety, that is low sanidine or orthoclase. This is found regardless of rock type (i.e., monzogranite versus pegmatite) and, therefore, the simple but generalized relationship of increasing ordering with increasing fluid pressure (e.g., Parsons and Boyd, 1971; Parsons, 1977; Parsons and Brown, 1984) does not apppear to strictly apply here. A similar situation exists in other large granitoid batholiths, such as parts of the nearby St. George Batholith of southern New Brunswick (Cherry and Trembath, 1978) or the Wiborg rapakivi massif of southern Finland (Vorma, 1971). At the same time exceptions to this generalization exist, as illustrated by samples 29B, 32 and 49 (Fig. 6) where triclinic phases exist with or 

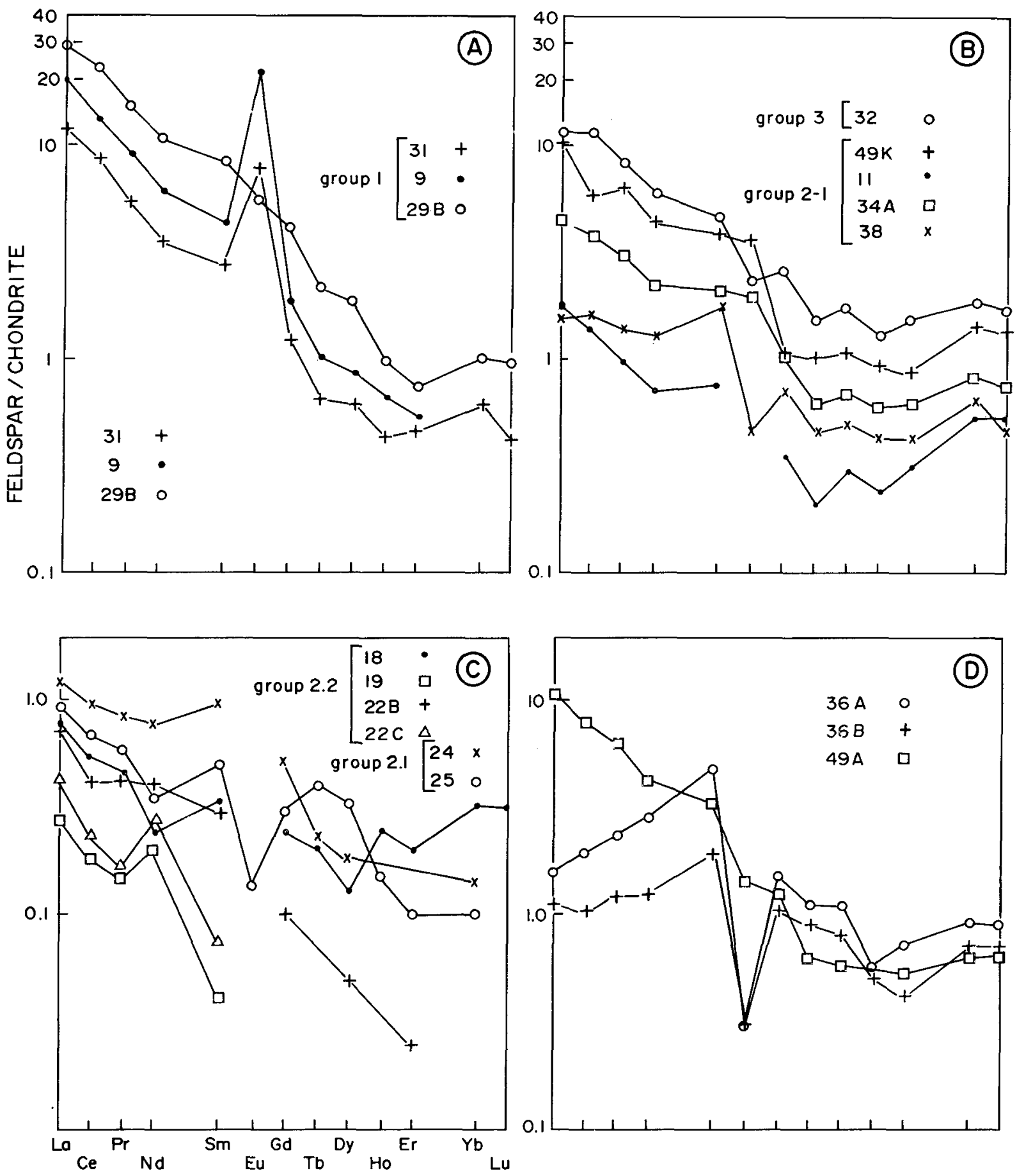

Fig. 5. Chondrite-normalized REE profiles for alkali feldspars, South Mountain Batholith (legend on lower left diagram applies to all the plots). The significance of the groupings $(1,2.1,2.2,3)$ is discussed in the text.

without monoclinic K-feldspar. We note here that in all three of these localities, fluids did play an important role in determining the observed phase assemblages. However, it is only in the case of sample 29B that apparently triclinic K-feldspar exists in isolation. The presence of grid twinning in this sample indicates that the feldspar inverted from a monoclinic structure during reequilibration at a temperature of $\angle 450^{\circ} \mathrm{C}$ (Bambauer and Bernotat, 1982; Parsons and Brown, 1984).

The presence of at least two additional occurrences of triclinic
K-feldspar within the South Mountain Batholith indicates that its development is not as restricted as it might appear. The first example is from the Digby deep drillhole (see fig. 9 of Clarke and Chatterjee (1988) for details). Although the shallow parts of the hole contain fresh granodiorite, deeper intersections are albitized and carbonatized (i.e., episyenite) with concomitant reddening of the K-feldspar due to incipient hematitization (cf. Lalonde and Martin, 1983). Diffractograms of K-feldspar (Fig. 8A) from relatively pristine granodiorite (MRRD-1) through variably al- 

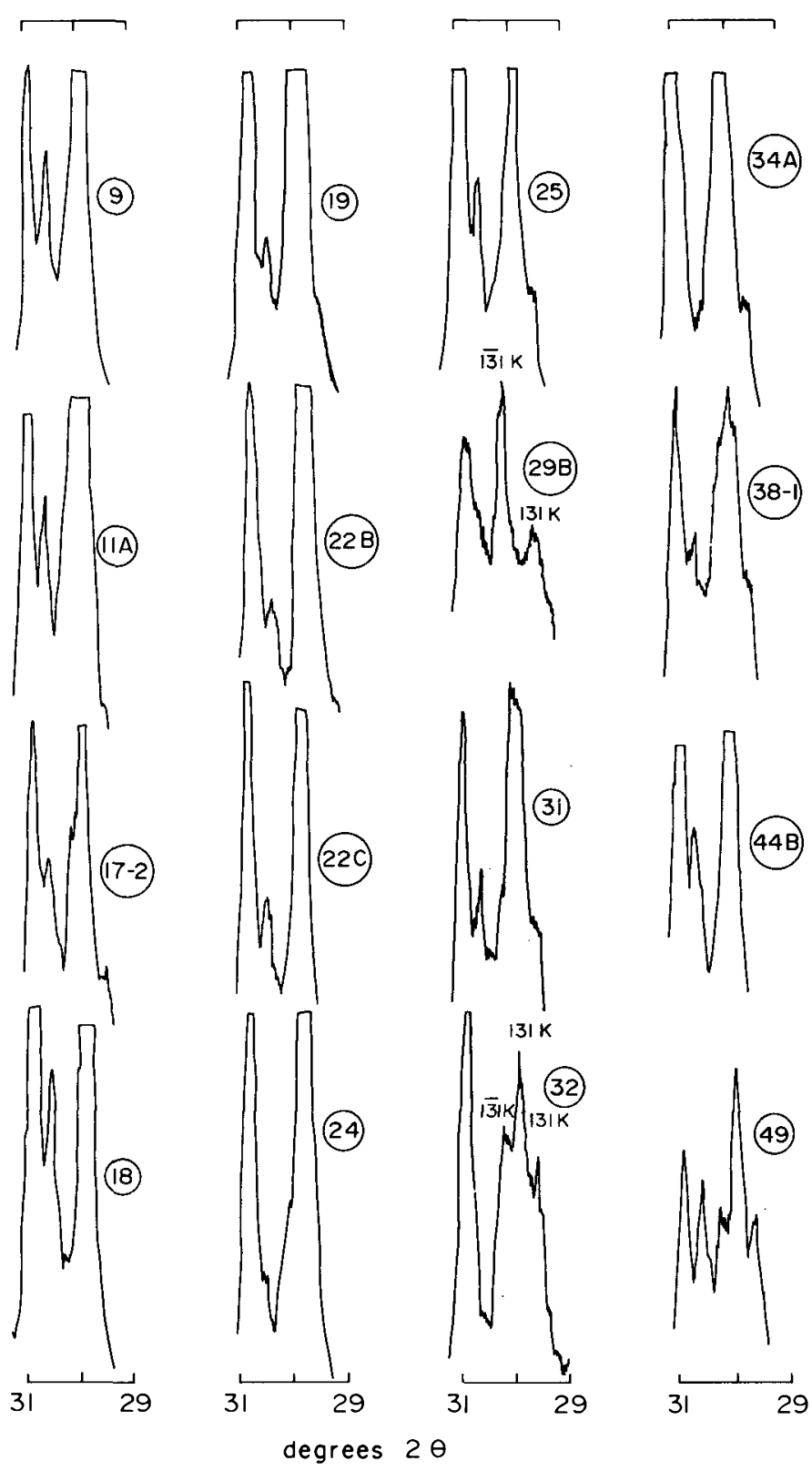

Fig. 6. X-ray diffractograms for K-feldspars from the South Mountain Batholith. The labelled peaks refer to the important (hkl) reflections used to distinguish between monoclinic and triclinic K-feldspar. For example, sample 9 is an orthoclase, sample 29B is a microcline and samples 32 and 49 represent mixtures. See text for more detailed discussion.

tered to intensely altered granitoid rock (MRRD-10,4,11) show the progression in development of triclinic domains, with broadening of the (131) $\mathrm{K}$ reflection. Thus, based on the feldspar structure, it is concluded that hydrothermal activity related to alteration of the granodiorite occurred in part within the stability field of microcline (i.e., $\leq 450^{\circ} \mathrm{C}$ ). The second example is from a pegmatite segregation within monzogranite near Herring Cove. At this locality, white K-feldspar is in part replaced by reddish Kfeldspar (designated $W$ and $R$, respectively, in Fig. 8) and the latter shows a marked broadening of the (131) $\mathrm{K}$ reflection compared to the fresh equivalent (Fig. 8B).

The presence of predominantly monoclinic K-feldspar within the suite of $\mathrm{K}$-feldspars examined is tentatively interpreted to reflect conditions, both physical and chemical, that collectively inhibited the development of triclinic K-feldspar. Thus, the overall peraluminous nature of the South Mountain Batholith (e.g., McKenzie and Clarke, 1975; MacDonald and Horne, 1988) may have been an important factor that retarded ordering, by analogy to previous studies that focused on experimental results (Martin, 1969) and natural occurrences (Guidotti, 1978; Guidotti et al., 1973; Cerny and Chapman, 1984). Cooling rate also plays a role (e.g., Cherry and Trembath, 1978), although its significance is difficult to ascertain (Parsons and Brown, 1984). The latter authors argued that there is a minimum cooling rate that will retard the ordering process, but it is difficult to isolate this single factor from among several potentially contributing influences.

In the case of the South Mountain Batholith, the role of latestage fluids is considered the most important factor in promoting ordering. In the areas where relatively highly ordered K-feldspar has been documented, there is clear independent evidence in terms of fluid inclusions, metasomatism and isotopic data that a late fluid phase has been present. In such areas an appropriate cooling rate must also have existed to facilitate the formation of microcline. In areas where similar fluid interaction occurred the thermal conditions may have been inappropriate for development of microcline or, alternatively, the temperature may have dropped too quickly and prevented ordering, since the monoclinic-triclinic inversion involves a kinetic barrier (Martin, 1974). Although the presence of disordered structural states of pegmatitic K-feldspar has in some cases been attributed to sudden escape of the volatile phase and, hence, stranding of a metastable structural phase (e.g., Martin and Falster, 1986), such a scenario is not considered realistic for the pegmatites of the South Mountain Batholith.

\section{Implications of mineral chemistry for chemical evolution of the batholith \\ Muscovite}

The four muscovite compositions reported herein all result from late-stage magmatic/hydrothermal processes and, as such, provide some information on the terminal stage in the evolution of the South Mountain Batholith. As noted above, sample 28 is chemically distinct from the others, and most of its chemistry is interpreted to reflect inheritance from the local monzogranite during greisenization (e.g., REE in Fig. 2). Chemical inheritance has also been noted in micas from greisen by Alderton $e t$ al. (1980), and in an earlier contribution Ham and Kontak (1988) presented evidence for similar behavior of greisen muscovite from the South Mountain Batholith. In fact, the REE pattem and trace element chemistry of this sample are quite similar to those of greisen muscovite from monzogranite presented by the latter authors (see Fig. 9 and below). In contrast, compositions of the remaining samples suggest products of relatively more evolved felsic melts. The REE pattems for samples 11 and 49 are the most depleted of any muscovite analyzed from the South Mountain Batholith, even more so than those from leucogranites (Ham and Kontak, 1988), and are notably less fractionated in terms of (La) 


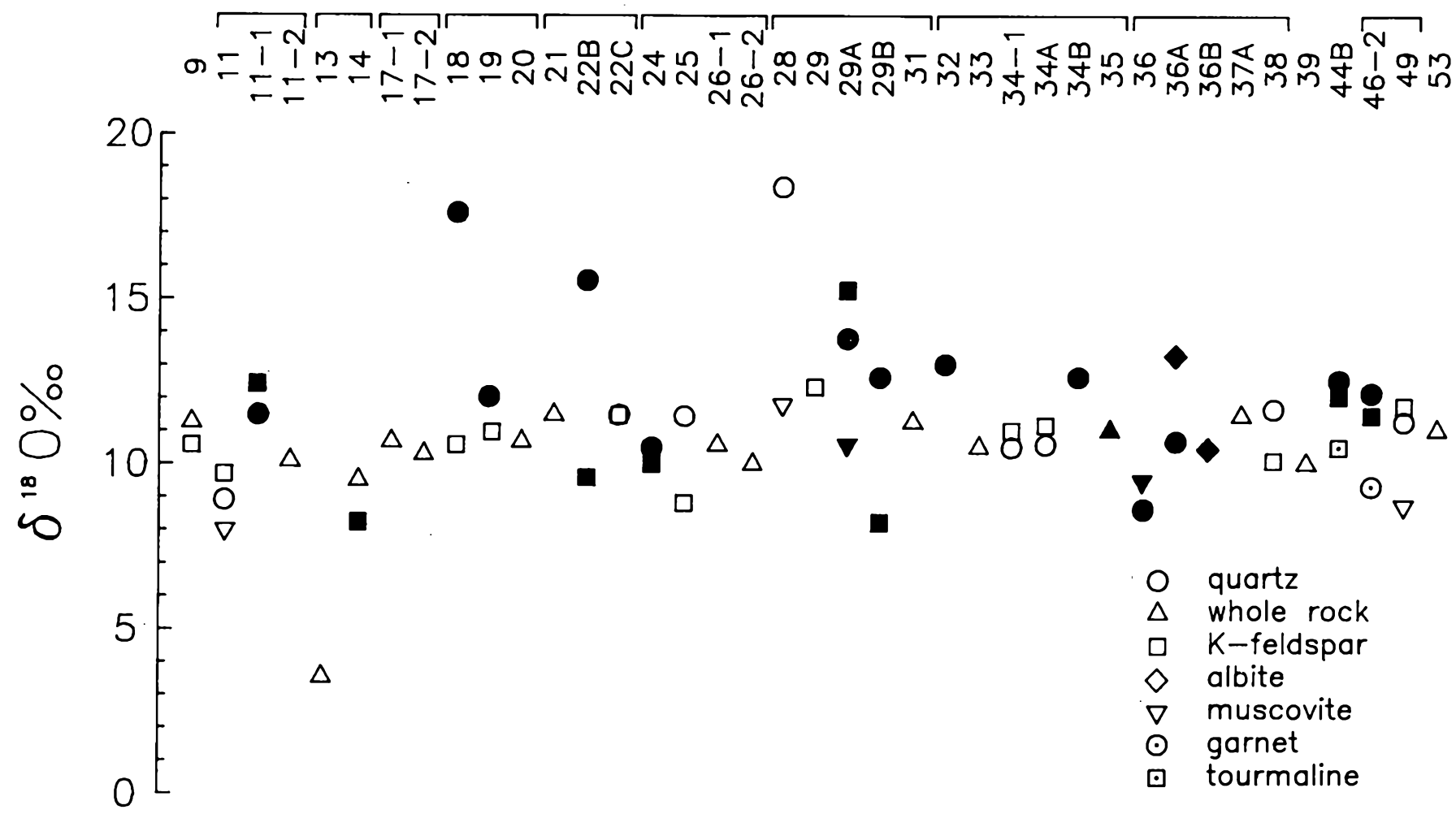

Fig. 7. Oxygen isotope values for mineral separates and whole-rocks from granites, pegmatites and greisens within the South Mountain Batholith (the samples are grouped according to locality; see Table 1 for sample locations). Note that the minerals (quartz, whole-rock, K-feldspar, albite and muscovite) are ordered in the manner they would appear if oxygen isotopic equilibrium was maintained. Note that for sample $22 \mathrm{C}$ quartz and $\mathrm{K}$ feldspar overlap with identical values. The infilled symbols represent earlier data of Kontak et al. (1988).

$\mathrm{Lu})_{\mathrm{N}}$. However, with respect to other trace elements (e.g., Li, $\mathrm{Rb}$, Cs), these two muscovite separates are depleted, not enriched, relative to the muscovite from leucogranite (see Fig. 9). Also in Figure 9, the distinct chemistry of sample 28 is again noted and it is apparent that its signature is typical of a less evolved system.

There are different Eu anomalies in the REE patterns for samples 11 and 49. In one case (49) a positive anomaly is noted, whereas in the other (11) a negative Eu anomaly is present. Given the otherwise similar chemistries of these samples, these differences may reflect one or more of the following processes: (1) a change in $\mathrm{fO}_{2}$ such that $\mathrm{Eu}^{2+}$ is relatively enriched in sample 11 compared to sample 49; (2) an Eu-bearing phase rich in $\mathrm{Eu}^{2+}$, such as feldspar, may have been dissolved, thereby releasing Eu into the fluid phase, with subsequent incorporation into muscovite; and (3) a relatively more oxidizing fluid may have deposited muscovite at Walker molybdenum (11) such that $\mathrm{Eu}^{3+}$ was favored over $\mathrm{Eu}^{2+}$.

\section{K-Feldspar}

The grouping of the major element chemistry of the K-feldspar samples, chiefly the $\mathrm{K} / \mathrm{Na}$ ratios or mole-\% Or (Table 3), is such that the compositional variation can be interpreted as reflecting different temperatures of crystallization from granitic melts \pm fluids (e.g., Parsons and Brown, 1984). Thus, the observed range in trace element chemistry of the $\mathrm{K}$-feldspar from different environments in part reflects this change in $\mathrm{K} / \mathrm{Na}$ of the $\mathrm{K}$ feldspar. It is, therefore, not surprising to find that the K-feldspar values collectively define a continuum in terms of chemistry, for example, the covariation of $\mathrm{Ba}$ and $\mathrm{Sr}$ versus $\mathrm{Rb}$ (Fig. 3), Rb/Sr versus REE (Fig. 4) and chondrite-normalized profiles (Fig. 5). This information is summarized in Figure 10 where all the Kfeldspar data have been normalized to a K-feldspar sample from granodiorite (sample MRRD-1 in Fig. 8A). In this diagram there is a rotation of the data such that $\mathrm{Li}, \mathrm{Rb}, \mathrm{Cs}$ and $\mathrm{Ga}$ increase and $\mathrm{Sr}, \mathrm{Ba}$ and $\mathrm{La}$ decrease with increasing fractionation. This continuum suggests that the medium from which the $\mathrm{K}$-feldspar samples crystallized evolved in a systematic and progressive manner, precisely the conclusions arrived at on the basis of whole-rock chemistry (e.g., Clarke and Muecke, 1981; Kontak et al., 1988; MacDonald and Horne, 1988).

Examination of the REE data in more detail shows that there is a marked change in the degree of fractionation from group 1 to group 2. This break is comparable to that observed between the REE patterns of monzogranite and leucogranite in the South Mountain Batholith (Kontak et al., 1988; see also Clarke and Muecke, 1981). In the latter samples Kontak et al. (1988) argued that a fluid phase had been partly responsible for stripping the melts of light REE via chloride complexes (Flynn and Burnham, 1978). The chondrite-normalized REE profiles of K-feldspar hosted by pegmatites are similarly depleted in light REE, suggestive of a similar process. 


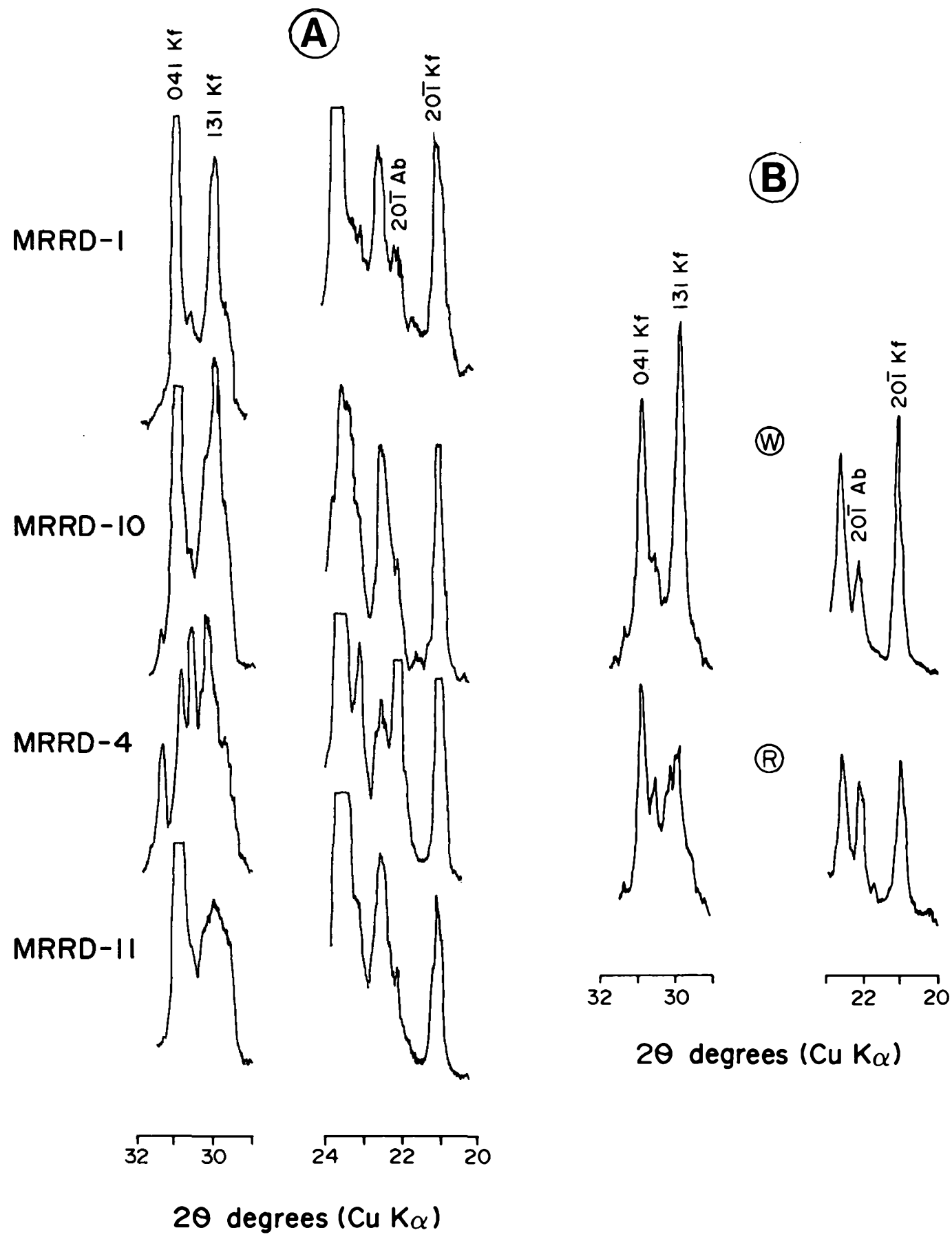

Fig. 8. X-ray diffractograms of $\mathrm{K}$-feldspars from the South Mountain Batholith. Note that $\mathrm{Kf}$ and $\mathrm{Ab}$ refer to reflections attributed to potassium- and sodium-bearing phases, respectively (i.e., orthoclase/microcline versus albite). (8A) Samples of K-feldspar showing progression from fresh granodiorite (MRRD-1) through variably altered granodiorite to the most intensely altered sample (MRRD-11). The dramatic increase in the Ab reflection (201) in sample MRRD-4 reflects albitization. (8B) Samples of K-feldspar from a pegmatite at Herring Cove. W and $R$ refer to white and red, respectively; the color of the samples analyzed.

The gradual change in the Eu anomaly, from values $\gg>1$ to $<<1$, is sympathetic with variations in other chemical parameters. The decreasing abundance of Eu is consistent with feldspar fractionation and militates against the model of Fowler and Doig (1983) in which large negative Eu anomalies in evolved granites are related to hydrothermal alteration and subsequent liberation of $\mathrm{Eu}$ as $\mathrm{Eu}^{3+}$. However, we note that the lack of a positive Eu anomaly for sample 29B may indicate that late greisen-forming fluids at this locality were relatively oxidizing, given the presence of positive Eu anomalies in other cases of group $1 \mathrm{~K}$ feldspar.

In contrast to other $\mathrm{K}$-feldspar samples in the suite, the metasomatized sample (32) shows some elemental abundances more typical of a monzogranite than a pegmatitic affiliation (Figs. 4, 5, 


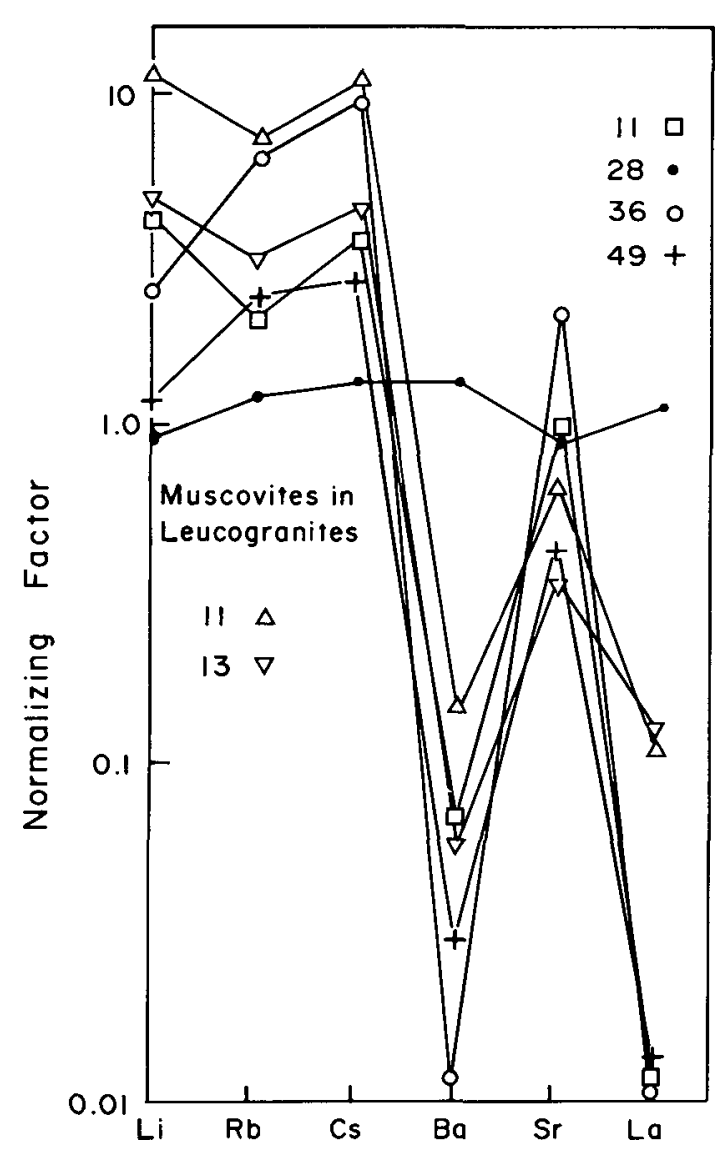

Fig. 9. Chemical data for muscovites from the South Mountain Batholith normalized to the chemistry of muscovite from a biotite-muscovite monzogranite (analysis 1 in Table 3 of Ham and Kontak, 1988). Also included for comparison are two muscovites from leucogranites $(11,13)$ as reported in Ham and Kontak (1988). Note the markedly different chemical profile for greisen sample 28 compared to the remaining samples from pegmatites.

10). This may suggest that the fluid from which this K-feldspar precipitated was derived from a less fractionated parental melt than that responsible for pegmatitic K-feldspar 34A.

The albite samples analyzed have comparable chemistries, except for the light REE which show divergent chondrite-normalized trends. This feature may reflect a relatively more evolved parental melt for samples 36A and 36B, compared to sample $49 \mathrm{~A}$, in light of the above discussion.

\section{Implications of oxygen isotope data}

The results of oxygen isotopic analyses have important implications with respect to (1) the source regions of melts, (2) equilibrium between mineral pairs and, hence, the degree of chemical equilibrium in the rock as a whole, and (3) interaction of the sample with a fluid phase and nature of the fluid reservoir (i.e., meteoric versus connate fluid). We have discussed the implications of the whole-rock data in terms of source regions elsewhere (Kontak et al., 1988), as have Longstaffe et al. (1980), and the present data set indicates no reason to modify earlier interpretations. Thus, the reader is referred to these references for a more detailed discussion.

The degree of equilibration of the mineral pairs can be assessed by examining the observed fractionation of ${ }^{18} \mathrm{O}$ between different minerals. The field for equilibrium fractionation of ${ }^{18} \mathrm{O}$ at high temperature (i.e., magmatic conditions) between quartz and $\mathrm{K}$ feldspar is shown in Figure 11, with the available data from the South Mountain Batholith superimposed. The region for magmatic conditions within the South Mountain Batholith is defined using data for granodiorite and monzogranite reported by Longstaffe et al. (1980); it is apparent that these samples are in isotopic equilibrium, as they fall within the predicted range for magmatic conditions (i.e., $\Delta_{\text {quarz-feldeper }}=0.5-2.0$ ). In addition, using the quartz-muscovite data of Longstaffe $e t$ al. (1980) and the appropriate fractionation factors, temperatures have been calculated (Table 4). The mean temperature of $599 \pm 65^{\circ} \mathrm{C}(\mathrm{n}=3)$ is sufficiently high to imply that mineral equilibria have been maintained in the granite samples. In contrast, quartz and feldspar samples in the present study, which come predominantly from pegmatites, scatter about the quartz-feldspar field of Longstaffe et al. (1980) such that the majority of quartz-feldspar fractionations are $>2.0 \%$ or $<0.5 \%$ and, hence, out of equilibrium. The dispersal of the data indicates exchange of the mineral(s) with relatively ${ }^{18} \mathrm{O}$-enriched $\left(\Delta_{\text {quarz-eldeper }}<0.5\right)$ or -depleted $\left(\Delta_{\text {quarza-feldeper }}>2\right)$ fluids (Fig. 11). In addition, calculated temperatures for the pegmatite localities, based on quartz-muscovite pairs (Table 4), indicate a large range from $1042^{\circ} \mathrm{C}$ to $319^{\circ} \mathrm{C}$. Whereas the former value is clearly too high for pegmatite formation, the three remaining temperatures $(578,506,319)$ indicate that (1) mineral equilibrium has been variably retained, and (2) some constraining temperature limits for further calculations of $\delta^{18} O_{\text {nuid }}$ are established.

In order to evaluate the origin and role of fluids in the late-stage evolution of the batholith it is necessary to calculate the $\delta^{18} \mathrm{O}_{\text {fuid }}$ assuming a realistic temperature, inferred from some independent line of evidence, and the appropriate mineral-water fractionation factor. In Figure 12 the ranges of $\delta^{18} \mathrm{O}$ values determined for quartz, $\mathrm{K}$-feldspar and muscovite are shown versus temperature with the $\delta^{18} O$ value of fluids in equilibrium with the minerals (as a function of $\mathrm{T}^{\mathrm{C}} \mathrm{C}$ and $\delta^{18} \mathrm{O}_{\text {minenn }}$ ) shown as a family of lines. Separate calculations have been made for muscovite (Table 4), albite (Table 5) and garnet (see below). The temperature range used in the calculations is ca. $350-500^{\circ} \mathrm{C}$ based on the following: (1) the temperature of formation of pegmatites in general and experimental work on granite systems (e.g., Tuttle and Bowen, 1958); (2) calculated temperatures based on $\delta^{18} O$ fractionation between quartz and muscovite (see above); (3) the presence of predominantly monoclinic $\mathrm{K}$-feldspar in the pegmatites, i.e, T $>450^{\circ} \mathrm{C}$; and (4) the temperature range in which exchange is likely to occur based on previous studies (see Taylor, 1978, 1988). Errors in estimated temperature at the high end of the scale result in minimal changes in calculated $\delta^{18} \mathrm{O}_{\text {nuid }}$ (see Fig. 12) since mineral-water isotopic fractionations decrease systematically at elevated temperatures, and there is little evidence in any of the areas examined for significant fluid interaction over a protracted time period at temperatures lower than those indicated in Figure 12. This latter point is supported by the absence of the appropriate alteration assemblages (e.g., clay alteration) and the lack of an 

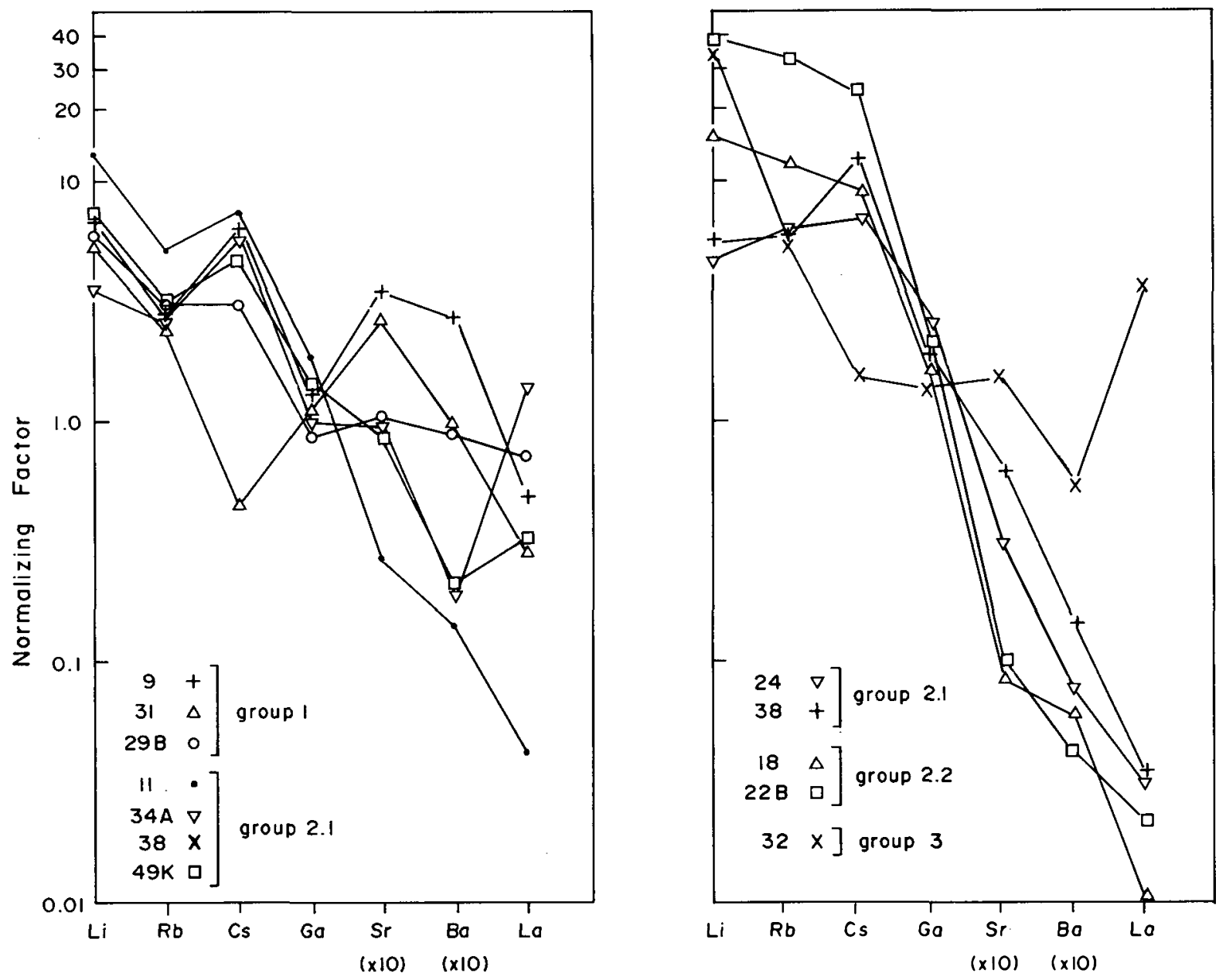

Fig. 10. Chemical data for K-feldspars from the South Mountain Batholith normalized to the chemistry of a K-feldspar (MRRD-1; unpublished data of Kontak) from a granodiorite in the Digby deep drillhole. Note that the data for $\mathrm{Sr}$ and $\mathrm{Ba}$ are multiplied by 10 for convenience of plotting.

extended array of data in Figure 11 (cf. Taylor, 1988).

Quartz separates collectively show a broad range in $\delta^{18} \mathrm{O}$ values and, accordingly, indicate a spectrum in $\delta^{18} \mathrm{O}_{\text {fuid }}$ of $16-4$ $\%$, using maximum variation in temperature constraints and $\delta^{18} \mathrm{O}_{\text {querz. }}$. However, of the 22 analyses in total, 16 fall in a narrower range corresponding to $\delta^{18} \mathrm{O}_{\text {fuid }}$ of $10.5-6 \%$; hence, the excursions to enriched and depleted fluid values are atypical. Magmatic fluids evolved from normal ${ }^{18} \mathrm{O}$ granitoids $\left(6<\delta^{18} \mathrm{O}\right.$ $<9)$ are generally considered to have $\delta^{18} \mathrm{O}$ values of 6 to $8 \%$, whereas high ${ }^{18} \mathrm{O}$ granitoids may have more enriched fluids. In detail we note that at single localities there may exist a large variation in the inferred $\delta^{18} \mathrm{O}_{\text {nuid }}$. For example, at Herring Cove a spread in $\delta^{18} \mathrm{O}_{\text {quaru }}$ of $5.4 \%$ would translate into an equivalent spread for $\delta^{18} \mathrm{O}_{\text {nuid }}$ (i.e., 11-6\%). Such a range is larger than can be explained by the inferred temperature range $\left(500-350^{\circ} \mathrm{C}\right.$ corresponds to $3 \%$ change) and suggests a mixing of fluids. A similar situation exists at the Keddy's and Reeves localities (Fig. 1 and Table 1), where the maximum variations in $\delta^{18} \mathrm{O}_{\text {quarz }}$ are 5.7 and 4.1, respectively. Smaller variations occur at the other localities, namely Pockwock $(0.7 \%)$, Morley's $(2.0 \%)$, Long Lake $(2.2 \%)$, Grassy Brook $(1.1 \%)$ and Walker molybdenum $(3.6 \%)$.

$\mathrm{K}$-feldspar separates collectively show a spread in $\delta^{18} \mathrm{O}$ of 8.2 to $15.1 \%$ and indicate a range in $\delta^{18} \mathrm{O}_{\text {fuid }}$ of $14-4 \%$, a value closely approximating that indicated by quartz. As with quartz, the sample with the most enriched $\delta^{18} O$ value is from the greisen at Herring Cove. Detailed examination of the individual localities again indicates that differences occur for multiple analyses of $\mathrm{K}$-feldspar from individual localities. The largest difference is found at Herring Cove $(7.0 \%)$, with much smaller variations at Keddy's $(0.4 \%)$, Reeves $(1.7 \%)$ and Grassy Brook $(1.2 \%)$. At Pockwock and Long Lake, identical values were obtained on separate K-feldspar samples. Multiple analyses of quartz from these same two localities also gave very similar results.

Muscovite separates define a narrow range in terms of $\delta^{18} \mathrm{O}$ from 8.2 to $12.0 \%$ which translates into a correspondingly small range for $\delta^{18} \mathrm{O}_{\text {flud }}$ of ca. 6.5 to $12 \%$. The $\delta^{18} \mathrm{O}_{\text {fluid }}$ values are presented in Table 4 using the temperatures derived from quartzmuscovite fractionations; they define a more restricted range from 9.1 to $10.7 \%$, depending on the fractionation factor used (see Table 4). Values of $\delta^{18} \mathrm{O}_{\text {nuid }}$ based on the muscovite data of Longstaffe et al. (1980; Table 4) define a comparable range (8$12 \%$ ) to that calculated above.

The results of calculations for fluids in equilibrium with the two albite samples from Morley's pegmatite indicate values spanning a broad range from 4 to $12 \%$, depending again on the 


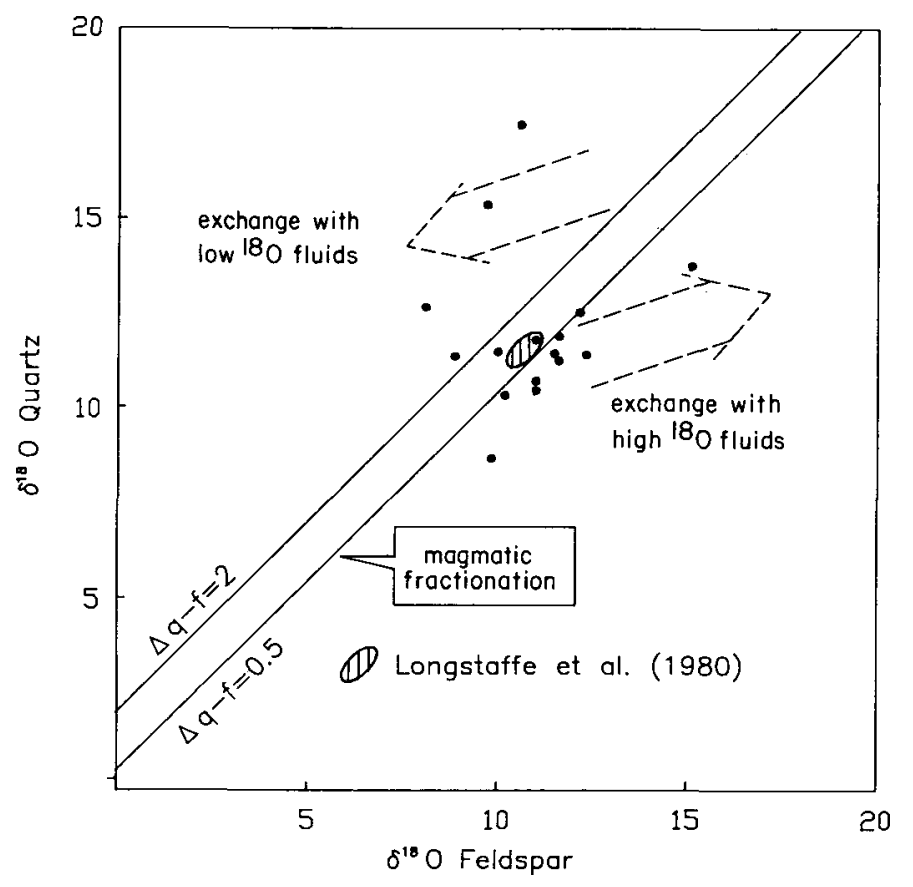

Fig. 11. Bivariate plot of oxygen isotopic data for coexisting quartz and K-feldspar in granites and pegmatites of the South Mountain Batholith. The trend for magmatic fractionation is inferred from the equilibrium fractionation of ${ }^{18} \mathrm{O}$ between quartz and feldspar at elevated temperatures. Field for granites (vertical lines) is defined using the data $(n=6)$ of Longstaffe et al. (1980). Note that most of the samples from pegmatite localities fall outside the field for magmatic fractionation and indicate disequilibrium conditions due to exchange of either one or both of the minerals with ${ }^{18} \mathrm{O}$-enriched (heavy) or -depleted (light) fluids.

fractionation factor used. These values fall within the range indicated by K-feldspar (see above). Again, the differences observed are unlikely to be related simply to a change in temperature of equilibration of the two feldspar samples.

The single garnet analysis reported equates to a $\delta^{18} \mathrm{O}_{\text {fuid }}$ value (using the fractionation factor of Bottinga and Javoy, 1975) of between $10.2\left(400^{\circ} \mathrm{C}\right)$ and $11.2 \%\left(600^{\circ} \mathrm{C}\right)$, depending upon the temperature used. From the detailed studies of Corey (1988) the higher temperature limit is probably more reasonable given the alteration assemblage present in the area.

The fractionation factor for tourmaline- $\mathrm{H}_{2} \mathrm{O}$ has not been experimentally determined and, therefore, a $\delta^{1} \mathrm{O}_{\text {fuid }}$ value cannot be independently derived. However, from empirical observation the $\delta^{18} \mathrm{O}$ of tourmaline is approximated by $\delta^{18} \mathrm{O}$ of $\mathrm{K}$-feldspar minus $0.5 \%$ (B.E. Taylor in Beaty et al., 1988) and the fractionation of $\delta^{18} \mathrm{O}$ between quartz and tourmaline from granitic pegmatites indicates that quartz is enriched by $2.0 \%$ (Taylor and Slack, 1984). If these assumptions are correct, then the quartz and tourmaline in sample 44B are in isotopic equilibrium $(\Delta=2.2$ $\%$ ), whereas the feldspar and tourmaline are not $(\Delta=1.8 \%$ ). The absolute $\delta^{18} \mathrm{O}$ value of $10.4 \%$ for the tourmaline is slightly greater than the range $(6-10.2 \%)$ for pegmatitic tourmaline compiled in Taylor and Slack (1984).

From the foregoing discussion it is apparent that whereas whole-rock $\delta^{18} \mathrm{O}$ values are relatively constant and define a small range (10.6 $\pm 0.5 \%$; Table 1 and Fig. 7), the $\delta^{18} O_{\text {mineril }}$ values are
Table 4. Calculated temperatures and fluid compositions for muscovite-quartz and muscovite$\mathrm{H}_{2} \mathrm{O}$ oxygen isotope equilibria.

\begin{tabular}{lllll}
\hline $\begin{array}{l}\text { Sample } \\
\#\end{array}$ & quartz-muscovite & $\mathrm{T}^{\circ} \mathrm{C}$ & \multicolumn{2}{c}{${ }^{18} \mathrm{O}_{\text {nuid }}$} \\
& & O\&T & B\&J
\end{tabular}

Kontak et al. (this study):

$\begin{array}{lcccc}11 & 0.7 & 1042 & - & - \\ 28 & 5.8 & 319 & 9.1 & 9.68 \\ 29 \mathrm{~A} & 3.1 & 506 & 10.77 & 10.77 \\ 36 & -0.4 & - & - & - \\ 49 & 2.5 & 578 & 9.4 & 9.27\end{array}$

Longstaffe et al. (1980):

$\begin{array}{lrrrc}210 & 3.0 & 517 & 8.47 & 9.82 \\ 211 & 1.9 & 675 & 11.14 & 12.0 \\ 1 & 2.3 & 607 & 10.21 & 11.26\end{array}$

Temperatures calculated using the quartz-muscovite mineral fractionation equation of Bottinga and Javoy (1975). O\&T refers to O'Neil and Taylor (1969) and B\&J refers to Bottinga and Javoy (1973). Note that for samples 11 and 36 fluid compostions are not calculated because of unrealistic temperature and fractionation values, respectively.

much more scattered. The mineral separates analyzed by Longstaffe et al. (1980; plotted in Fig. 11) indicate equilibrium on a whole-rock scale; in contrast the data for pegmatites generally reflect disequilibrium conditions. There is evidence from structural studies of the $\mathrm{K}$-feldspar analyzed that fluid-rock interaction persisted below $450^{\circ} \mathrm{C}$ to produce triclinic domains. Fractionation of ${ }^{18} \mathrm{O}$ between quartz and muscovite corroborates this (Table 4). Thus, the oxygen isotope data indicate that in the late-stage evolution of the batholith, fluid-rock interaction resulted in disequilibria among coexisting silicate phases with respect to ${ }^{18} \mathrm{O}$ in which feldspar and muscovite undergo preferential re-equilibration. Given the restricted range in $\delta^{18} \mathrm{O}_{\text {whole-rock }}$ and the temperature range over which fluid interaction occurred, it apppears necessary to involve additional fluids to account for the large variations in $\delta^{18} \mathrm{O}_{\text {nuid }}$ documented above.

\section{Nature of fluids in the late-stage evolution of the batholith}

The range of $\delta^{18} \mathrm{O}_{\text {fuid }}$ of magmatic provenance is generally between +5.5 and $+10.0 \%$, excluding exceptional circumstances, whereas the range of $\delta^{18} \mathrm{O}_{\text {fivid }}$ derived from metamorphic rocks is generally +5 to $+25 \%$ (Taylor, 1979). Given that the whole-rock oxygen isotope data for the batholith fall near the spectrum for normal igneous rocks, we feel justified in concluding that fluids derived from these granitoid rocks should correspond to the spectrum for magmatic fluids. Most of the fluid compositions inferred above fall in the range of 5-10\%, or slightly greater, therefore indicating that a magmatic derivation is appropriate. However, excursions from the magmatic field are indicated by several samples which suggest that infiltration occurred by both $\delta^{18} \mathrm{O}$-enriched and -depleted fluids. The light $\delta^{18} \mathrm{O}$ signatures are indicated by single quartz values from Walker molybdenum $(8.9 \%)$ and Morley's pegmatite $(8.9 \%)$, K- 

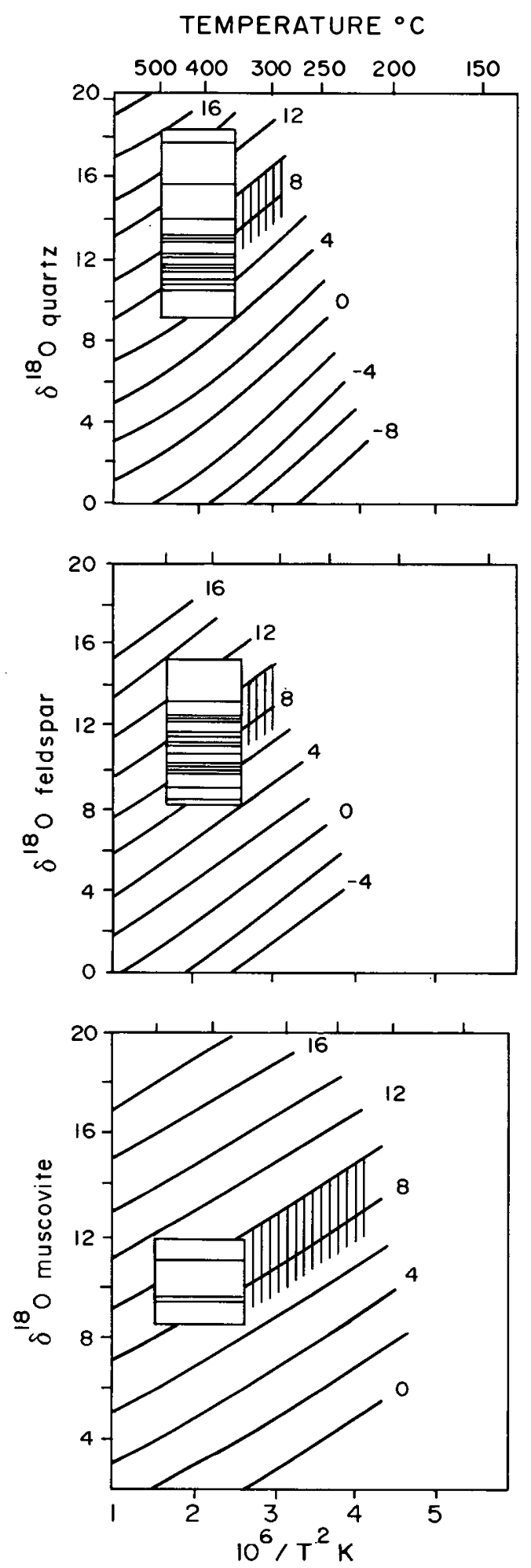

Fig. 12. Plots of temperature $\left({ }^{\circ} \mathrm{C}\right)$ versus oxygen isotopic composition of quartz, $\mathrm{K}$-feldspar and muscovite as given in Table 1 . The temperature range of ca. $500-350^{\circ} \mathrm{C}$ outlined by the boxes is discussed in the text. The family of lines in the diagrams represent the ${ }^{18} \mathrm{O}_{\text {flid }}$ in equilibrium with the minerals at defined values of ${ }^{18} \mathrm{O}_{\text {minenl }}$ and temperature. The vertical lines indicate the range for magmatic fluids derived from normal granites. Figures have been designed using the appropriate mineral- $\mathrm{H}_{2} \mathrm{O}$ fractionation factors for quartz (Clayton et al., 1972), K-feldspar (O'Neil and Taylor, 1967) and muscovite (Bottinga and Javoy, 1973).
Table 5. Calculated ${ }^{18} \mathrm{O}_{\text {nuid }}$ in equilibrium with albite for different temperatures.

\begin{tabular}{lcc}
\hline Temperature & \#36A & $\# 36 \mathrm{~B}$ \\
\hline $500^{\circ} \mathrm{C}$ & $11.7 / 11.6$ & $8.8 / 8.7$ \\
$400^{\circ} \mathrm{C}$ & $10.4 / 10.0$ & $7.5 / 1$ \\
$300^{\circ} \mathrm{C}$ & $7.4 / 7.3$ & $5.5 / 4.4$ \\
\hline
\end{tabular}

Note that the higher values for each temperature were calculated using the albite- $\mathrm{H}_{2} \mathrm{O}$ equilibria of Matsuhisa et al. (1979) while the lower values were obtained using the equation of Bottinga and Javoy (1973).

feldspar values from Turner tin ( $8.2 \%$ ), Herring Cove greisen $(8.1 \%)$ and Grassy Brook $(8.9 \%)$, and a single whole-rock value from Turner tin $(3.6 \%$ ) (see Fig. 12 to compute the equivalent $\delta^{18} \mathrm{O}_{\text {nidid }}$ value).

The presence of ${ }^{18} \mathrm{O}$-enriched fluids is indicated for two pegmatite localities (Reeves, Keddy's) and the greisen at Herring Cove. The explanation favoured for the origin of these fluids involves derivation of an ${ }^{18} \mathrm{O}$-enriched fluid from the Meguma Group. However, additional evidence for more widespread infiltration of metamorphic fluids is found in the overall range of the data for the mineral separates and, therefore, similarly large spread of $\delta^{18} \mathrm{O}_{\text {fuid }}$ that would be in equilibrium with these phases. As noted earlier, the inferred range of temperature used in Figure 12 is not large enough to generate the observed differences in fluid compositions. The restricted range in whole-rock $\delta^{18} O$ values indicates that fluid interaction with this medium cannot account for the spread. However, variable degrees of infiltration and fluid/rock equilibration by both ${ }^{18} \mathrm{O}$-enriched and -depleted fluids could account for the observed variations. Interaction with an externally derived fluid also would account for the disposition of points in Figure 11, which indicates that both quartz and Kfeldspar have exchanged with such fluids.

The local variation in the $\delta^{18} \mathrm{O}$ composition of mineral phases within single pegmatite localities (e.g., Keddy's, Reeves) or the greisen at Herring Cove indicates heterogeneity on a very small scale with respect to the isotopic composition of the fluid. Several workers (London, 1986; Morgan and London, 1987; Thomas and Spooner, 1988; Thomas et al., 1990) have documented the involvement of different fluids in the border zone of the Tanco pegmatite. The mixing of fluids of distal origins is well documented in the formation of, for example, skarn W (e.g., Bowman et al., 1985; Brown et al., 1985; Gerstner et al., 1989) and porphyry $\mathrm{Cu}$ (Reynolds and Beane, 1985) deposits. Thus, the documentation of apparently extraneous fluids in the late-stage evolution of the batholith is not without parallel.

\section{CONCLUSIONS}

This study of the physical and chemical evolution of the eastern part of the South Mountain Batholith supports the following conclusions:

(1) Mineral compositions of K-feldspar, albite and muscovite corroborate earlier geochemical investigations based on both whole-rock and mineral chemistry. The mineral chemistries of 
analyzed phases define a continuum with respect to the magmatic evolution of the batholith. In the more primitive magmatic stage of the batholith, crystal fractionation of the major silicate phases lead to depletion of elements such as $\mathrm{Ba}, \mathrm{Sr}$ and $\Sigma R E E$ with enrichment of $\mathrm{Li}, \mathrm{Cs}$ and $\mathrm{Rb}$ (e.g., Fig. 10). The influence of a fluid phase during the late-stage evolution of the batholith is indicated by the shape of light REE profiles in chondrite-normalized plots of the K-feldspar, therefore corroborating similar conclusions based on whole-rock studies (Clarke and Muecke, 1981; Kontak et al., 1988).

(2) Where greisen zones are developed, chemical inheritance occurs such that the precursor rock plays a dominant role in determining the chemistry of alteration phases (e.g., muscovite at Herring Cove).

(3) The gradual decrease in $\mathrm{Eu} / \mathrm{Eu}^{*}$ values for $\mathrm{K}$-feldspar suggests that observed Eu anomalies in this mineral reflect feldspar fractionation within the melt and are not the result of metasomatic processes (cf. Fowler and Doig, 1983).

(4) Oxygen isotopic data for quartz, feldspars and muscovite confirm earlier conclusions based on a more limited database. Whereas isotopic equilibrium was established and maintained among mineral phases from granodiorites and monzogranites, widespread disequilibrium is present among the mineral phases sampled in pegmatite and a greisen, signifying preferential latestage re-equilibration of feldspar and muscovite.

(5) Calculated values of $\delta^{18} O_{\text {fluids }}$ indicate that whereas most of the compositions fall in or near the magmatic range, deviations to higher $(10+18 \%)$ and lower $(+4 \%)$ values occur. This information, in conjunction with larger than expected spreads in isotopic data for single mineral phases in the temperature range considered $\left(500-350^{\circ} \mathrm{C}\right)$ at the same localities, suggests that exotic fluids (i.e., with respect to local igneous environment) infiltrated these areas.

(6) Structural determinations of the K-feldspar separates used in the geochemical and isotopic studies indicate that monoclinic structures dominate. However, triclinic feldspar does occur in areas where observations suggest extreme fluid/rock interaction (e.g., alteration zones). The general absence of highly ordered feldspars in pegmatitic environments probably reflects a rapid cooling rate owing to sudden uplift (?) such that the poorly ordered K-feldspar remains as a stranded metastable phase.

\section{ACKNOWLEDGEMENTS}

This research was funded through NSERC grants to D.F. Strong and R. Kerrich. D.J. Kontak acknowledges financial support in the form of a post-doctoral fellowship through funds from D.F. Strong (NSERC Grant No. A7975). The stable isotope laboratory at the University of Saskatchewan is supported by an NSERC Infrastructure Grant. Part of this research was also funded by the Nova Scotia Department of Mines and Energy through the Canada - Nova Scotia Mineral Development Agreement (1984-1989). D.J. Kontak especially thanks the South Mountain Batholith crew for providing accommodation and field support during the 1985 field season. The major element chemistry was capably done by $G$. Andrews, and the trace elements by Drs. H. Longerich and S. Jackson, all at Memorial University, St.
John's, Newfoundland. Nova Scotia Department of Mines and Energy personnel are thanked for their help in preparing the figures and text.

ALDERTON, D.H.M., PEARCE, J.A., and POTTS, P.J. 1980. Rare earth element mobility during granite alteration: evidence from southwest England. Earth and Planetary Science Letters, 49, pp. 149-165.

BAMBAUER, H.U. and BERNOTAT, W.H. 1982. The microcline/ sanidine transformation isograd in metamorphic regions. I. Composition and structural state of alkali feldspars from granitoid rocks of two N-S traverses across the Aar Massif and Gotthard "Massif", Swiss Alps. Schweiz. Mineralogie et Petrographie Mitteilungen, 62, pp. 185-230.

BEATY, D.W., HAHN, G.A., and THRELKELD, W.E. 1988. Field, isotopic, and chemical studies of tourmaline-bearing rocks in the Belt-Purcell Supergroup: genetic constraints and exploration significance for Sullivan type ore deposits. Canadian Journal of Earth Sciences, 25 , pp. 392-402.

BOTTINGA, Y. and JAVOY, M. 1973. Corsments of oxygen isotope geothermometry. Earth and Planetary Science Letters, 20, pp. 250 265.

1975. Oxygen isotope partitioning among the minerals in igneous and metamorphic rocks. Review of Geophysics and Space Physics, 13, pp. 401-418.

BOWMAN, J.R., COVERT, J.J., CLARK, A.H., and MATHIESON, G.A. 1985. The Can Tung E zone scheelite skarn orebody, Tungsten, Northwest Territories: oxygen, hydrogen, and carbon isotope studies. Economic Geology, 80, pp. 1872-1895.

BROWN, P.E., BOWMAN, J.R., and KELLY, W.C. 1985. Petrologic and stable isotope constraints on the source and evolution of skam forming fluids at Pine Creek, Califomia. Economic Geology, 80, pp. 72-95.

CERNY, P. and CHAPMAN, R. 1984. Paragenesis, chemistry and structural state of adularia from granitic pegmatites. Bulletin de Mineralogie, 107, pp. 369-384.

CHAREST, M.H. 1976. Petrology, geochemistry and mineralization of the New Ross area, Lunenburg County, Nova Scotia. M.Sc. thesis, Dalhousie University, Halifax, Nova Scotia, 192 p.

CHAREST, M.H., FARLEY, E.J., and CLARKE, D.B. 1985. The northwestem part of the New Ross-Vaughan complex: petrology, geochemistry and mineral deposits. In Guide to the Granites and Mineral Deposits of Southwestern Nova Scotia. Edited by A.K. Chatterjee and D.B. Clarke. Nova Scotia Department of Mines and Energy, preprint of Paper 85-3, pp. 29-40.

CHATTERJEE, A.K. and STRONG, D.F. 1984. Rare-earth and other element variations in greisens and granites associated with the East Kemptville tin deposit, Nova Scotia, Canada. Transactions, Institute of Mining and Metallurgy, 93, pp. B59-B70.

CHATTERJEE, A.K., STRONG, D.F., and CLARKE, D.B. 1985a. Petrology of the polymetallic quartz-topaz greisen at East Kemptville. In Guide to the Granites and Mineral Deposits of Southwestem Nova Scotia. Edited by A.K. Chatterjee and D.B. Clarke. Nova Scotia Department of Mines and Energy, preprint of Paper 85-3, pp. 156196.

CHATTERJEE, A.K., STRONG, D.F., CLARKE, D.B, ROBERTSON, J., POLLOCK, D., and MUECKE, G.K. 1985b. Geochemistry of the granodiorite hosting mineralization at Millet Brook. In Guide to the Granites and Mineral Deposits of Southwestern Nova Scotia. Edited by A.K. Chatterjee and D.B. Clarke. Nova Scotia Department of Mines and Energy, preprint of Paper 85-3, pp. 64-114.

CHERRY, M.E. and TREMBATH, L.T. 1978. Structural state and composition of alkali feldspars in granites of the St. George pluton, 
southwestem New Brunswick. Mineralogical Magazine, 42, pp. 391399.

CLARKE, D.B. and CHATTERJEE, A.K. 1988. Physical and chemical processes in the South Mountain Batholith. In Recent Advances in the Geology of Granite-Related Mineral Deposits. Edited by R.P. Taylor and D.F. Strong. Canadian Institute of Mining and Metallurgy, Special Volume 39, pp. 223-233.

CLARKE, D.B. and MUECKE, G.K. 1981. Geochemical evolution of the South Mountain Batholith, Nova Scotia: rare-earth-element evidence. Canadian Mineralogist, 19, pp. 133-146.

CLAYTON, R.N. and MAYEDA,T.K. 1963. The use of bromine pentafluoride in the extraction of oxygen from oxides and silicates for isotopic analysis. Geochimica et Cosmochimica Acta, 27, pp. 43-52.

CLAYTON, R.N., O'NEIL, J.R., and MAYEDA, T.K. 1972. Oxygen isotope exchange between quartz and water. Joumal of Geophysical Research, 77, pp. 3057-3067.

COREY, M.A. 1988. An occurrence of metasomatic aluminosilicates related to high alumina hydrothermal alteration within the South Mountain Batholith, Nova Scotia. Maritime Sediments and Atlantic Geology, 24, pp. 83-96.

FLYNN, R.T. and BURNHAM, C.W. 1978. An experimental determination of rare earth partition coefficients between a chloride containing vapor phase and silicate melts. Geochimica et Cosmochimica Acta, 42, pp. 685-701.

FOWLER, A.D. and DOIG, R. 1983. The significance of europium anomalies in the REE spectra of granites and pegmatites, Mont Laurier, Quebec. Geochimica et Cosmochimica Acta, 47, pp. 11311137.

GERSTNER, M.R., BOWMAN, J.R., and PASTERIS, J.D. 1989. Skam formation at the MacMillan Pass tungsten deposit (Mactung), Yukon and Northwest Territories. I. P-T-X-V characterization of the methane-bearing, skam-forming fluids. Canadian Mineralogist, 27, pp. 545-563.

GUIDOTTI, C.V. 1978. Muscovite and K-feldspar from two-mica adamellite in northwestern Maine: composition and petrogenetic implications. American Mineralogist, 63, pp. 750-753.

GUIDOTTI, C.V., HERD, H.H., andTUTTLE, C.L. 1973. Composition and structural state of K-feldspars from K-feldspar + sillimanite grade rocks in northwestern Maine. American Mineralogist, 58, pp. 705716.

HAM, L.J. and KONTAK, D.J. 1988. A textural and chemical study of white mica in the South Mountain Batholith, Nova Scotia: primary versus secondary origin. Maritime Sediments and Atlantic Geology, 24, pp. 111-121.

JENNER, G.A., LONGERICH, H.P., JACKSON, S.E., and FRYER, B.J. 1990. ICP-MS - a powerful tool for high precision trace element analysis in earth sciences: evidence from analysis of selected USGS reference samples. Chemical Geology. In press.

JIRANEK, J. 1982. A rapid X-ray method of assessing the structural state of monoclinic K-feldspars. Lithos, 15, pp. 85-87.

KONTAK, D.J. 1988a. Geochemistry of alkali feldspars, South Mountain Batholith, Nova Scotia: implications for petrogenesis. In Program with Abstracts, Atlantic Geoscience Society Meeting, Antigonish, March 1988.

1988b. East Kemptville project: whole-rock and mineral chemistry, stable isotopes and fluid inclusion studies - a progress report. In Mines and Minerals Branch, Report of Activities 1988, Part A. Edited by D.R. MacDonald and Y. Brown. Nova Scotia Department of Mines and Energy, Report 88-3, pp. 83-95.

KONTAK, D.J. and COREY, M. 1988. Metasomatic origin of spessartine-rich garnet in the South Mountain Batholith, Nova Scotia. Canadian Mineralogist, 26, pp. 315-334.
KONTAK, D.J. and STRONG, D.F. 1988. Geochemical studies of alkali feldspars in lithophile element-rich granitic suites from Newfoundland, Nova Scotia and Peru. Geological Association of Canada, Program with Abstracts, 13, p. A68.

KONTAK, D.J., KERRICH, R., and STRONG, D.F. 1988. Crystalmelt \pm fluid phase equilibria versus late-stage fluid-rock interaction in granitoid rocks of the South Mountain Batholith, Nova Scotia: whole rock geochemistry and oxygen isotope evidence. Maritime Sediments and Atlantic Geology, 24, pp. 97-110.

LALONDE, A.E. and MARTIN, R.F. 1983. The Baie-des-Moutons syenitic complex, La Tabatiere, Quebec. I. Petrography and feldspar mineralogy. Canadian Mineralogist, 21, pp. 65-79.

LOGOTHETIS, J. 1985. Economic geology of the New Ross-Vaughan complex. In Guide to the Granites and Mineral Deposits of Southwestern Nova Scotia. Edited by A.K. Chatterjee and D.B. Clarke. Nova Scotia Department of Mines and Energy, preprint of Paper 85 3, pp. 41-62.

LONDON, D. 1986. Magmatic-hydrothermal transition in the Tanco rare metal pegmatite: evidence from fluid inclusions and phase equilibrium experiments. American Mineralogist, 71, pp. 376-395.

LONGERICH, H.P., JENNER, G.A., FRYER, B.J., and JACKSON, S.E. 1990. Inductively coupled plasma - mass spectrometric analysis of geological samples: a critical evaluation based on case studies. Chemical Geology. In press.

LONGSTAFFE, F.J., SMITH, T.E., and MUEHLENBACHS, K. 1980. Oxygen isotope evidence for the genesis of Upper Paleozoic granitoids from southwestern Nova Scotia. Canadian Journal of Earth Sciences, 17, pp. 132-141.

MACDONALD, M.A. and HORNE, R.J. 1988. Petrology of the zoned, peraluminous Halifax Pluton, south-central Nova Scotia. Maritime Sediments and Atlantic Geology, 24, pp. 33-46.

MACDONALD, M.A. and O'REILLY, G.A. 1989. Gold enrichment associated with post-magmatic processes in the South Mountain Batholith, southwestern Nova Scotia. In Mines and Minerals Branch, Report of Activities 1988, Part B. Edited by Y. Brown and D.R. MacDonald. Nova Scotia Department of Mines and Energy, Report 89-1, pp. 13-27.

MACDONALD, M.A., COREY, M.C., HAM, L.J., and HORNE, R.J. 1987. South Mountain Batholith project: project report. In Mines and Minerals Branch, Report of Activities 1987, Part A. Edited by J.L. Bates and D.R. MacDonald. Nova Scotia Department of Mines and Energy, Report 87-5, pp. 99-104.

MARTIN, R.F. 1969. The hydrothermal synthesis of low albite. Contributions to Mineralogy and Petrology, 23, pp. 323-339.

1974. Controls of ordering and subsolidus phase relations in the alkali feldspars. In The Feldspars. Edited by W.S. McKenzie and J. Zussman. Proceedings of NATO Advanced Study Institute, Manchester University Press, Manchester, England, pp. 313-336.

MARTIN, R.F. and FALSTER, A.U. 1986. Proterozoic sanidine and microcline in pegmatite, Wausau complex, Wisconsin. Canadian Mineralogist, 24, pp. 709-716.

MATSUHISA, Y., GOLDSMITH, J.R., and CLAYTON, R.N. 1979. Oxygen isotopic fractionation in the system quartz-albite-anorthitewater. Geochimica et Cosmochimica Acta, 43, pp. 1131-1140.

MCKENZIE, C.B. and CLARKE, D.B. 1975. Petrology of the South Mountain Batholith, Nova Scotia. Canadian Journal of Earth Sciences, 12, pp. 1209-1218.

MCLELLAN, S.M. 1989. Rare earth elements in sedimentary rocks: influence of provenance and sedimentary processes. In Geochemistry and Mineralogy of Rare Earth Elements. Edited by B.R. Lipin and G.A. McKay. Mineralogical Society of America, Reviews in Mineralogy, 21, pp. 169-200. 
MORGAN, G.B., VI, and LONDON, D. 1987. Alteration of amphibolitic wallrocks around the Tanco rare-element pegmatite, Bernic Lake, Manitoba. American Mineralogist, 72, pp. 1097-1121.

O'NEIL, J.R. and TAYLOR, H.P., Jr. 1967. The oxygen isotope and cation exchange chemistry of feldspars. American Mineralogist, 52. pp. 1414-1437.

1969. Oxygen isotope equilibrium between muscovite and water. Journal of Geophysical Research, 74, pp. 6012-6022.

O'NEIL, J.R., CLAYTON, R.N., and MAYEDA, T.K. 1969. Oxygen isotope exchange reactions between clay minerals and water. Geochimica et Cosmochimica Acta, 40, pp. 241-246.

O'REILLY, G.A., FARLEY, E.J., and CHAREST, M.H. 1982. Metasomatic-hydrothermal mineral deposits of the New Ross-Mahone Bay area, Nova Scotia. Nova Scotia Department of Mines and Energy, Paper 82-2, $96 \mathrm{p}$.

PARSONS, I. 1977. Feldspars and fluids in cooling plutons. Mineralogical Magazine, 42, pp. 1-17.

PARSONS, I., and BOYD, R. 1971. Distribution of potassium feldspar polymorphs in intrusive sequences. Mineralogical Magazine, 38, pp. 295-311.

PARSONS, I. and BROWN, W.L. 1984. Feldspars and the thermal history of igneous rocks. In Feldspars and Feldspathoids. Edited by W.L. Brown. D. Reidel Publishing Company, Boston, Massachusetts, pp. 317-372.

REYNOLDS, T.J. and BEANE, R.E. 1985. Evolution of hydrothermal fluid characteristics at the Santa Rita, New Mexico, porphyry copper deposit. Economic Geology, 80, pp. 1328-1347.

STRONG, D.F. and LONGERICH, H.P. 1985. The inductively coupled plasma/mass spectrometer (ICP/MS). Geoscience Canada, 12, pp. 72-75.

TAYLOR, B.E. and SLACK, J.F. 1984. Tourmalines from Appalachian-Caledonian massive sulphide deposits: textural, chemical and isotopic relationships. Economic Geology, 79, pp. 1703-1726.
TAYLOR, H.P., Jr. 1968. The oxygen isotope geochemistry of igneous rocks. Contributions to Mineralogy and Petrology, 19, pp. 1-71.

1978. Oxygen and hydrogen isotope studies of plutonic granitic rocks. Earth and Planetary Science Letters, 38, pp. 177-210.

1979. Oxygen and hydrogen isotope relationships in hydrothermal mineral deposits. In Geochemistry of Hydrothermal Ore Deposits. Edited by H.L. Barnes. John Wiley and Sons, Inc., New York, pp. 236 276.

1988. Oxygen, hydrogen and strontium isotope constraints on the origins of granites. Transactions of the Royal Society of Edinburgh, Earth Sciences, 79, pp. 317-338.

TAYLOR, H.P., Jr. and SHEPPARD, S.M.F. 1986. Igneous rocks: I. Processes of isotopic fractionation and isotope systematics. In Stable Isotopes in High Temperature Geological Processes. Edited by J.W. Valley, H.P. Taylor, Jr., and J.R. O'Neil. Mineralogical Society of America, Reviews in Mineralogy, 16, pp. 227-273.

THOMAS, A.V. and SPOONER, E.T.C. 1988. Fluid inclusions in the system $\mathrm{H}_{2} \mathrm{O}-\mathrm{CH}_{4}-\mathrm{NaCl}-\mathrm{CO}_{2}$ from metasomatic tourmaline within the border unit of the Tanco zoned granitic pegmatite, S.E. Manitoba. Geochimica et Cosmochimica Acta, 52, pp. 1065-1075.

THOMAS, A.V., PASTERIS, J.D., BRAY, C.J., AND SPOONER, E.T.C. 1990. $\mathrm{H}_{2} \mathrm{O}-\mathrm{CH}_{4}-\mathrm{NaCl}-\mathrm{CO}_{2}$ inclusions from the footwall contact of the Tanco granitic pegmatite: estimates of internal pressure and composition from microthermometry, Laser Raman spectroscopy, and gas chromatography. Geochimica et Cosmochimica Acta, 54, pp. 559-573.

TUTTLE, O.F. AND BOWEN, N.L. 1958. Origin of granite in the light of experimental studies in the system $\mathrm{NaAlSi}_{3} \mathrm{O}_{8}-\mathrm{KAlSi}_{3} \mathrm{O}_{8}-\mathrm{SiO}_{2}$ $\mathrm{H}_{2} \mathrm{O}$. Geological Society of America, Memoir 74.

VORMA, A. 1971. Alkali feldspars of the Wiborg rapakivi massif in south eastern Finland. Bulletin Communication Geological Society of Finland, 246, 70 p. 